\title{
ANTITRUST: A NEW TOOL FOR ORGANIZED LABOR?†
}

\author{
James M. Altman $\dagger \dagger$
}

Historically, the antitrust laws ${ }^{1}$ have victimized organized labor. Although Congress passed the Sherman Act ${ }^{2}$ to combat the threat to a free market economy posed by trusts and other big business combinations, ${ }^{3}$ the Act initially was invoked against labor unions. ${ }^{4}$ The Supreme Court's 1908 decision in Loewe v. Lawlor ${ }^{5}$ that union activities were not wholly immune from antitrust liability led directly to devastating treble damage awards against individual union members. ${ }^{6}$ For the next thirty years, Sherman Act injunctions crippled organized labor's use of its chief economic weapons-strikes and secondary boycotts. ${ }^{7}$ It is not surprising, then, that organized labor's attitude toward the antitrust laws has been primarily defensive: unions generally have

\section{Copyright $\odot 1982$ by James $M$. Altman}

$\dagger$ After this Article went to press, the Supreme Court decided Associated Gen. Contractors v. California State Council of Carpenters, 51 U.S.L.W. 4139 (U.S. Feb. 22, 1983). The Court held that unions lacked standing under $\S 4$ of the Clayton Act, 15 U.S.G. $\S 15$ (1976), to bring a treble damage action based upon an alleged conspiracy by a multiemployer bargaining unit and others to coerce its members, competitors, and customers not to deal with construction general contractors and subcontractors who had signed collective bargaining agreements with the plaintiff unions. See infra text accompanying notes 13-14, 251-55.

H Member, Schulman \& Abarbanel of New York, N.Y. B.A. 1971, J.D. 1975, Yale University. Member, New York, District of Columbia, and Connecticut Bars. This Article is based on a presentation made at the AFL-GIO Lawyers Conference held in Minneapolis, Minn., in May, 1982.

The author would like to express his gratitude and appreciation to Howard Schulman and Ellen Schecter for presenting opportunities to develop this Article, and to Jay Levy-Warren, whose penetrating questions and insightful analysis regarding some of the issues discussed in this Article helped greatly.

1 The antitrust laws referred to in this paper are the Sherman Act, 26 Stat. 209 (1890) (codified as amended at 15 U.S.C. $\S \S 1-7$ (1976)), and the Clayton Act, 38 Stat. 730 (1914) (codified as amended at 15 U.S.C. $\S \S 12-27,18$ U.S.C. $\S \S 402,660,3285,3691$, and 29 U.S.C. $\$ \$ 52-53$ (1976)).

26 Stat. 209 (1890) (codified as amended at 15 U.S.C. $\$ \S 1-7$ (1976)).

s See, e.g., 21 CONG. REC. 2456-57 (1890); see also United States v. South-Eastern Underwriters Ass'n, 322 U.S. 533, 553-55 (1944); Apex Hosiery Co. v. Leader, 310 U.S. 469, $492-93$ (1940).

1 In 12 of the first 13 successful antitrust lawsuits the defendants were unions. E. BERMAN, LABOR AND THE SHERMAN ACT 3 (1930).

3208 U.S. 274 (1908).

- The treble damage award against individual union members and officers caused many of them to lose their homes. See Atkinson v. Sinclair Ref. Co., 370 U.S. 238, 248 (1962); see also Savings Bank of Danbury v. Loewe, 242 U.S. 357 (1917) (attachment of savings accounts).

'See, e.g., Bedford Cut Stone Co. v. Journeymen Stone Cutters' Ass'n, 274 U.S. 37 (1927)(refusal to handle nonunion goods); Coronado Coal Co. v. United Mine Workers, 268 U.S. 295 (1925) (strike); Duplex Printing Press Co. v. Deering, 254 U.S. 443 (1921) (secondary boycott). See generally F. FRANKFURTER \& N. GREENE, THE LABOR INJUNCTION (1930). 
tried to strengthen and broaden the argument that their activities are exempt from antitrust liability. ${ }^{8}$

Perhaps as a consequence, organized labor has made no sustained attempt to use the antitrust laws as a sword against anticompetitive conduct by employers that redounds to its detriment. Until recently, the few suits filed by labor organizations attempting to use the Act against employers were usually dismissed, primarily on two grounds. First, courts have held unions' antitrust complaints legally insufficient because the alleged employers' combinations were not found to restrain commercial competition in markets for goods or services. ${ }^{9}$ Second, unions and their members have been held to lack standing to assert antitrust claims against employers. ${ }^{10}$ Some courts have also stated that suits that would survive these two initial hurdles would nevertheless succumb to a third: the argument that the statutory labor exemption from antitrust liability, based on the Clayton and Norris-LaGuardia Acts, ${ }^{11}$ also protects employers. ${ }^{12}$

These three issues - sufficiency of the complaint, standing, and the scope of the labor exemption - are now before the Supreme Court in California State Council of Carpenters v. Associated General Contractors. $^{13}$ In the decision below, the Ninth Circuit upheld the suffi-

- Labor organizations are protected by two exemptions from the antitrust laws. The first of these is the "statutory" exemption based on $\S 6$ of the Clayton Act, 15 U.S.C. $\S 17$ (1976), $\S 20$ of the Clayton Act, 29 U.S.C. $\$ 52$ (1976), and $\$ \S 4,5$, and 13 of the Norris-LaGuardia Act, 29 U.S.C. $\$ \S 104,105$, and $113(1976)$. See infra notes 87-113 and accompanying text. The second is the "nonstatutory" exemption based on our national labor policy favoring collective bargaining. See Local Union No. 189, Amalgamated Meat Cutters v. Jewel Tea, 381 U.S. 676, 689-90 (1965); see also Connell Const. Co. v. Plumbers \& Steamfitters Local Union No. 100, 421 U.S. 616, 622 (1975).

- See, e.g., Prepmore Apparel v. Amalgamated Clothing Workers, 431 F.2d 1004, 1007 (5th Cir. 1970), cert. dismissed, 404 U.S. 801 (1971); Kennedy v. Long Island R.R., 319 F.2d 366, 373 (2d Cir.), cert. denied, 375 U.S. 830 (1963); United Brick \& Clay Workers v. Junction City Clay Co., 158 F.2d 552, 554 (6th Cir. 1946); Clune v. Publishers' Ass'n, 214 F. Supp. 520, 525, 531 (S.D.N.Y.), affd, 314 F.2d 343 (2d Cir. 1963) (per curiam).

${ }^{10}$ See, e.g., Conference of Studio Unions v. Loew's, Inc., 193 F.2d 51, 54-55 (9th Cir. 1951), cert. denied, 342 U.S. 919 (1952); Schatte v. International Alliance of Theatrical Stage Employees, 182 F.2d 158 (9th Cir. 1950); Clune, 214 F. Supp. at 525. These cases all involved claims of anti-union activity by employers. Employees challenging other kinds of anticompetitive behavior on the part of employers have also been held to lack standing under the antitrust laws. See Reibert v. Atlantic Richfield Co., 471 F.2d 727 (10th Cir.), cert. denied, 411 U.S. 938 (1973)(merger); Bywater v. Matsushita Elec. Indus. Co., 1971 Trade Cas. (CCH) ๆ 73,759 (S.D.N.Y. 1971) (dumping).

11 See supra note 8.

12 See, e.g., Clune, 214 F. Supp. at 528-31 (injunctive relief against employers under Sherman Act prohibited by $\S 20$ of Clayton Act and by Norris-LaGuardia Act).

13648 F.2d 527 (9th Gir. 1980), cert. granted, 102 S. Ct. 998 (1982). Also before the Court is the question whether an antitrust action can be brought when the challenged employers' conduct involves alleged unfair labor practices within the exclusive jurisdiction of the NLRB. After Connell Constr. Co. v. Plumbers \& Steamfitters Local Union No. 100, 421 U.S. 616 (1975), in which the Court held that an agreement could violate both \$ 8(e) of the Labor-Management Relations Act and the antitrust laws, a preemption attack on a labor antitrust complaint seems frivolous. 
ciency of the labor organizations' claim. The complaint alleged that the defendant association had encouraged general contractors to form nonunion shops and divisions and that the association's member firms had coerced landowners and general contractors to deal only with firms that had not signed collective bargaining agreements with the unions. ${ }^{14}$ The court also denied the employers' motion to dismiss on grounds of standing and rejected the employers' effort to clothe themselves with the protection of the statutory labor exemption.

This Article analyzes these issues in order to determine whether and under what circumstances organized labor can use the antitrust laws as a sword. Part I concludes that both labor organizations and unionized employees may raise legally sufficient Sherman Act challenges to employers' conduct that has an overall negative impact on the competitive structure of either product or labor markets. Part II analyzes the legislative history of the statutory labor exemption and its treatment by the Supreme Court, demonstrating that the exemption should not be interpreted to immunize employer conduct from antitrust liability. Part III concludes that unions and employees should have standing to obtain treble damages for at least some employer violations of the antitrust laws.

The analytic approach adopted here differs somewhat from that of most courts adjudicating labor antitrust cases challenging employers' conduct. Those courts have reasoned primarily on the basis of the Supreme Court's post-1940 labor antitrust decisions, ${ }^{16}$ nearly all of which have involved labor organizations seeking to avoid antitrust liability by claiming a labor exemption. ${ }^{16}$ The Supreme Court's general discussions of antitrust liability in those cases appear as background to its focus on the exemption issue. They therefore provide a less reliable guide for analyzing the question of employers' antitrust liability than the traditional framework of antitrust law involving businesses.

That conclusion applies particularly to the employers' argument that preemption is required because antitrust remedies are inconsistent with NLRB remedies or those of the federal courts under $\S 301$ of the Labor-Management Relations Act. The Connell Court expressly rejected the view that labor law and antitrust remedies are inconsistent. See Connell, 421 U.S. at 626, 634, \& 635 n.17.

14 648 F.2d at 529-30.

15 See, e.g., Associated Gen. Contractors, 648 F.2d at 531-32 (concluding that the plaintiff unions stated a sufficient Sherman Act claim by resting heavily upon Connell, a case rejecting a union's claim for exemption from antitrust liability). But cf. id. at $531 \mathrm{n} .5$ (citing group boycott cases involving entrepreneurs).

18 See, e.g., H.A. Artists \& Assocs. v. Actors' Equity Ass'n, 451 U.S. 704 (1981); Connell, 421 U.S. 616 (1975); United Mine Workers v. Pennington, 381 U.S. 657 (1965); Jewel Tea; Allen Bradley Co. v. Local Union No. 3, Int'l Bhd. of Elec. Workers, 325 U.S. 797 (1945); United States v. Hutcheson, 312 U.S. 219 (1941); Apex Hosiery Co. v. Leader, 310 U.S. 469 (1940). 
For the purpose of analysis, this Article makes the following simplifying assumptions: first, that the challenged employers' conduct is jointly undertaken in a manner constituting or furthering a conspiracy or combination; ${ }^{17}$ second, that the conduct is not undertaken jointly with labor groups and does not fall within the nonstatutory labor exemption from antitrust liability for conduct that furthers the national policy favoring collective bargaining: ${ }^{18}$ and third, that the challenged employers' conduct is in or affects interstate commerce. ${ }^{19}$

Resolution of the standing and the statutory labor exemption issues logically depends upon the nature of the particular employers' conduct claimed to violate the antitrust laws. The issue of substantive liability therefore will be considered first.

\section{Valid Section 1 Claims Against Employers}

\section{A. The Traditional Section 1 Framework}

Section 1 of the Sherman Act prohibits "[e]very contract, combination ... or conspiracy in restraint of trade or commerce."20 Because this language is so vague and all-encompassing, recourse to it is virtually useless in establishing section 1's meaning. Consequently, it is necessary to look to the Court's "traditional framework of analysis under $\S 1^{\prime \prime 21}$ in order to determine when employers' conduct is unlawful.

The purpose of the antitrust laws, and of section 1 in particular, is to promote economic competition. ${ }^{22}$ As Justice Brandeis observed in Chicago Board of Trade v. United States, "[e]very agreement concerning trade, every regulation of trade, restrains."2s Clearly, however, not all such restraints create antitrust liability. The Court has relied on the concept of a "market" to determine whether challenged conduct is suffi-

17 Section 1 of the Sherman Act prohibits "[e]very contract, combination . . . or conspiracy, in restraint of trade . . . " 15 U.S.C. $\S 1$ (1976). Since it takes more than one party to agree, conspire, or combine, $\S 1$ by its terms requires a multiplicity of economic entities. See, e.g., United States v. Colgate \& Co., 250 U.S. 300 (1919). The assumption throughout this Article is that this $\$ 1$ prerequisite has been satisfied by the challenged employers' conduct.

${ }_{18}$ See Connell, 421 U.S. at 622 . The question of when employers may invoke the nonstatutory exemption is beyond the scope of this Article.

10 Section 1 of the Sherman Act prohibits restraints of "trade or commerce among the several States . . . " 15 U.S.C. $\S 1$ (1976). Since in passing the Act Congress exercised its power under the commerce clause to its fullest extent, see Atlantic Cleaners \& Dyers v. United States, 286 U.S. 427,435 (1932), a $\$ 1$ claim can satisfy the requisite connection with interstate commerce under either the "in commerce" or the "effect on commerce" theory. See McClain v. Real Estate Bd., 444 U.S. 232, 242 (1980).

${ }^{20} 15$ U.S.C. $\$ 1$ (1976).

21 Continental T.V. v. GTE Sylvania, 433 U.S. 36, 49 (1977).

23 See National Soc'y of Professional Engineers v. United States, 435 U.S. 679, 688 (1978); Northern Pac. Ry. v. United States, 356 U.S. 1, 4 (1958).

${ }^{23} 246$ U.S. 231, 238 (1918). 
ciently anticompetitive to violate section 1 . Although the types and structures of particular markets may vary, in the perfectly competitive market numerous buyers and numerous sellers of a particular good or service act in accordance with the classical economic laws of supply and demand. ${ }^{24}$ In such a market, price is the "central nervous system of the economy",25 it reflects the optimal allocation of resources and maximizes consumer welfare. ${ }^{26}$ Under the prevailing section 1 standard, the "rule of reason," consequences of the challenged action to ascertain whether on the whole it suppresses or destroys competition in a market. ${ }^{28}$ If the conduct has that effect, it is an unreasonable restraint of trade, regardless of its nature. In the case of certain conduct whose anticompetitive effects are "pernicious" and well-known, such as price-fixing and group boy$\operatorname{cotts}^{29}$ the Court has established a rule of per se unreasonableness, substituting proof that such conduct occurred for the elaborate economic investigation required under the rule of reason..$^{30}$

Although this traditional framework has been used primarily in cases involving businesses, its emphasis on competitive market structure is also evident in an early labor antitrust case, Apex Hosiery Co. v. Leader. $^{31}$ In the spring of 1937, Local 706 of the Federation of Full Fashioned Hosiery Workers requested a closed shop agreement ${ }^{\mathbf{3 2}}$ from Apex, a Philadelphia manufacturer. Following several refusals by the company, Local 706 forcibly seized the plant and commenced a sitdown strike that foreclosed all hosiery production for more than three months and prevented interstate shipment of 130,000 dozen pairs of finished stockings. The company sued Local 706 under section 1 of the Act, and the jury returned a verdict and an award of damages against the union that the court trebled.

14 See United States v. E.I. duPont de Nemours \& Co., 351 U.S. 377, 392 (1956) ("[i]f a large number of buyers and sellers deal freely in a standardized product . . . we have complete or pure competition").

${ }^{25}$ United States v. Socony-Vacuum Oil Co., 310 U.S. 150, 226 n.59 (1940).

26 See Northern Pacific, 356 U.S. at 4.

${ }^{27}$ See generally Standard Oil Co. v. United States, 221 U.S. 1 (1911).

${ }^{28}$ See National Soc'y of Professional Engineers, 435 U.S. at 687-92; Chicago Bd. of Trade v. United States, 246 U.S. 231, 238 (1918); Standard Oil, 221 U.S. at 72-75.

29 For purposes of this Article, a group boycott is defined as an agreement between two or more persons to the effect that one or more of them will not buy from, sell to, or in any other way deal commercially with some other economic entity not a party to the agreement under any circumstances or unless some particular set of conditions is met. This definition is a slight modification of that proposed in Bauer, Per Se Illegality of Concerted Refusals to Deal: A Rule Ripe for Reexamination, 79 CoLUM. L. REV. 685, 685 n.5 (1979).

so See, e.g., Northern Pacific Ry. v. United States, 356 U.S. 1, 5 (1958).

31310 U.S. 469 (1940).

32 A closed shop agreement provides that an employer will hire and retain only union members. See R. GORMAN, BASIC TEXT ON LABOR LAW 639-42 (1976). 
The question before the Supreme Court was whether preventing the interstate shipment of the finished stockings was the kind of "restraint of trade or commerce" prohibited by section $1 .^{33}$ Chief Justice Hughes, joined by Justices McReynolds and Roberts, thought it was. They argued in dissent that obstructing the shipment of goods in interstate commerce "falls directly within the language of the Sherman Act in its natural import"34 and that there was no reason to narrow that literal reading of section 1.

Justice Stone, speaking for the Court, disagreed. He formulated a general view of the meaning of "restraint of trade" by focusing on "three circumstances relating to the history and application of the Act which are of striking significance." ${ }^{\text {"3s }}$ First, the Act's legislative history revealed the evil at which it was aimed:

The end sought was the prevention of restraints to free competition in business and commercial transactions which tended to restrict production, raise prices or otherwise control the market to the detriment of purchasers or consumers of goods and services, all of which had come to be regarded as a special form of public injury. ${ }^{36}$

Second, the Court had held the Act applicable only in cases involving "some form of restraint upon commercial competition in the marketing of goods or services." 37 Third, "contracts for the restriction or suppression of competition in the market, agreements to fix prices, divide marketing territories, apportion customers, restrict production and the like practices" were illegal and unenforceable under the common-law doctrine of restraint of trade, from which the Act originated and drew its scope. ${ }^{38}$ These restraints were condemned at common law and thus prohibited by the Act because in most cases their purpose or effect was to raise or fix market prices. ${ }^{38}$

Applying his conclusion that a "restraint of trade" required some substantial effect on the competitive structure of a market and therefore ultimately upon market price, ${ }^{\text {to }}$ Stone held that preventing the interstate shipment of finished stockings did not violate section 1 . Although Local 706's strike restrained the flow of interstate commerce, "the delay of these shipments was not intended to have and had no effect on prices

ss 310 U.S. at 487,490 .

s4 Id, at 517.

ss Id. at 490.

se Id. at 493 (footnote omitted). The pertinent legislative history is discussed at 310 U.S. at 493 n.15.

s7 Id. at 495 (footnote omitted).

ss Id. at 497-501.

so Id. at 497 .

${ }^{40}$ Id. at $500-01$. 
of hosiery in the market."41 Accordingly, Stone found that no restraint of trade violating section 1 had been shown.

Stone's approach to labor antitrust questions in Apex was eclipsed a year later, when Justice Frankfurter pioneered a different approach in United States v. Hutcheson. ${ }^{42}$ Stone's focus on whether the challenged conduct was the kind of restraint prohibited by the Act was superseded by what appeared at first to be a more convenient question, whether the challenged conduct was exempt from antitrust liability by virtue of the Clayton and Norris-LaGuardia Acts. ${ }^{43}$ But the Hutcheson approach has led to the creation of labor exemptions so factually complicated and bounded by such uncertain contours that at least one district court has wondered whether the Apex approach might not be preferable. ${ }^{44}$ Thus, Stone's approach, which always retained its validity if not its desirability, ${ }^{45}$ may be used more frequently in the future.

\section{B. Application to Employers' Conduct}

\section{Employers' Anti-Union Conduct}

Antitrust challenges to employers' anti-union conduct should be analyzed under the Apex approach and the traditional section 1 framework, ${ }^{46}$ not under the complex and confusing Hutcheson approach that is adopted when unions are defendants. Measured against the traditional standard, such challenges will succeed only if the employers' conduct is aimed at or results in an "unreasonable" restraint on competition: some impairment of the competitive structure of a market not justified by some pro-competitive effect of that conduct. Thus, courts uniformly have dismissed union antitrust complaints challenging employers' anti-union conduct that has neither the purpose nor the effect of impairing the competitive structure in any market. For example, courts have held that a defensive lockout by employers acting jointly in order to force a union's agreement to bargaining demands does not in itself violate section $1 .{ }^{47}$ Similarly, the creation and maintenance of an

41 Id. at 501 .

12312 U.S. 219 (1941).

is Sec infra text accompanying notes 104-13.

"Home Box Office v. Directors Guild, 531 F. Supp. 578, 613 n.17 (S.D.N.Y. 1982) ("The complexities and uncertainties of labor-antitrust law have reached such proportions that perhaps courts should begin their analysis of such cases by examining whether an antitrust violation ... has been alleged or shown").

45 Apex has been cited with approval in the Supreme Court's two most recent labor antitrust decisions. H.A. Artists \& Assocs. v. Actors' Equity Ass'n, 451 U.S. 704, 715 n.16 (1981); Connell Const. Co. v. Plumbers \& Steamfitters Local Union No. 100, 421 U.S. 616, 636 (1975).

18 See supra text accompanying notes 20-41.

47 See, e.g., Plumbers \& Steamfitters Local 598 v. Morris, 511 F. Supp. 1298 (E.D. Wash. 
employers' strike insurance plan or other mutual aid pact has been held not to violate section $1 .^{48}$ One employer's supplying strike breakers to enable a struck employer to continue operations does not violate that section..$^{49}$ Nor do employers violate section 1 when one employer helps another refuse to bargain, thereby injuring the union. ${ }^{50}$ Citing Apex, federal courts dismissed the union's complaint in each of these cases because there were no allegations suggesting that the employers' conduct restrained "commercial competition." Thus, under current case law, employers do not violate section 1 when they conspire, agree, or combine soley to destroy a union.

\section{Anticompetitive Acts Affecting a Product Market}

Unions have stated legally sufficient claims, however, when they have alleged some sort of employers' group boycott excluding unionsignatory employers from a "product market" (defined here as any market other than those service markets in which the service bought and sold is labor). ${ }^{51}$ In Associated General Contractors, ${ }^{\mathrm{b2}}$ the Ninth Circuit refused to dismiss the unions' complaint because the alleged employers' boycott of union-signatory firms hurt not only the plaintiff unions but also the boycotted union-signatory general contractors and subcontractors. Thus, the alleged agreement restrained competition in two product markets, that for general contractors' services and that for subcontractors' services. One district court has applied similar reasoning to an employers' agreement to select a general contractor for a construction project through a closed bidding process in which only nonunionized general contractors were invited to bid. The court held that the

1981); Clune v. Publishers' Ass'n, 214 F. Supp. 520 (S.D.N.Y.), af'd, 314 F.2d 343 (2d Cir. 1963).

${ }^{48}$ See, e.g., Kennedy v. Long Island R.R., 319 F.2d 366 (2d Cir.), cert. denied, 375 U.S. 830 (1963).

6 See, e.g., Amalgamated Meat Cutters v. Wetterau Foods, 597 F.2d 133 (8th Gir. 1979); United Brick \& Clay Workers v. Junction City Clay Co., 158 F.2d 552 (6th Cir. 1946).

so Sec, e.g., Prepmore Apparel v. Amalgamated Clothing Workers, 431 F.2d 1004, 1006-07 (5th Gir. 1970), cert. dismissed, 404 U.S. 801 (1971).

s1 The distinction between labor markets and service markets may appear unclear in certain instances - for example, in the case of self-employed professionals or entrepreneurs, who sell both a "service" and their own labor. In most cases, however, a distinction can be drawn fairly easily. In California State Council of Carpenters v. Associated Gen. Contractors, 648 F.2d 527 (9th Cir. 1980), cert. granted, 102 S. Ct. 998 (1982), for example, the defendant contractors compete in a service market - the market for building construction services. The members of the plaintiff unions, however, compete in a labor market - the service they are selling is their own labor.

${ }^{32}$ California State Council of Carpenters v. Associated Gen. Contractors, 648 F.2d 527 (9th Cir. 1980), cert. granted, 102 S. Ct. 998 (1982); see also Carpenter's Local Union No. 1846 v. Pratt-Farnsworth, Inc., 690 F.2d 489, 531-35, (5th Cir. 1982) (concerted refusal to deal with union-signatory contractors). 
agreement would violate section 1 , if proven. ${ }^{53}$ The courts in both cases concluded that unreasonable restrictions would be placed upon free and unfettered competition in the relevant market if unionized firms were prevented from competing because of the employers' preference for nonunion firms.

In cases involving sham unions, bona fide unions have overcome motions to dismiss for failure to state a claim because their complaints have been construed to allege an unreasonable restraint upon competition in a product market. In International Association of Heat \& Frost Insulators v. United Contractors Ass'n, ${ }^{\text {s4 }}$ twenty-eight construction unions sued the United Contractors Association, a trade association of employers in the construction business in Pennsylvania, along with the Trades and Crafts Union (TCU), the purported collective bargaining representative of those employers' employees. The complaint alleged that the employer association and TCU had conspired to eliminate competition in the construction industry in western Pennsylvania. The means to accomplish that objective focused on the labor market: by dominating and assisting TGU, then establishing it as the collective bargaining representative of their employees and executing a sham collective bargaining agreement with it, the conspiring employers paid their employees lower wages than other construction employers in western Pennsylvania that had collective bargaining agreements with bona fide unions, such as the plaintiffs. Paying lower wages, in turn, gave the conspiring employers a competitive advantage in job-bidding over bona fide, union-signatory construction employers. The district court dismissed the complaint, holding that the labor exemptions to the antitrust laws immunized the defendants' actions from liability. The Third Gircuit reversed.

The appellate court's analysis began with the observation that the district court had not considered the legal significance of the allegation that conspiring employers were also TCU's members and officers. If TCU really were a dominated labor organization, reasoned the court, then it was not exempt from antitrust liability. ${ }^{55}$ The collective bargaining agreement sub judice was, therefore, an agreement among employers increasing their margin of profit as entrepreneurs which should

ss See Carpenters Local Union No. 1846 v. E.I. Du Pont de Nemours \& Co., 110 L.R.R.M. 3140, 3144 (E.D. La. 1981); see also East Central Ohio Bldg. \& Construction Trades Council v. Landmark, Inc., No. 76-371 (N.D. Ohio April 26, 1977) (agreement to hire subcontractors on a "merit shop," i.e., nonunion, basis).

st 483 F.2d 384 (3d Cir. 1973), modified, 494 F.2d 1353 (1974); see also, Tugboat, Inc., v. Mobile Towing Co., 534 F.2d 1172 (5th Cir. 1976) ( union has standing to sue); Carpenters Dist. Council v. United Contractors Ass'n, 484 F.2d 119 (6th Cir. 1973), modified, 539 F.2d 1092 (1976).

ss 483 F.2d at $389-90$. 
not be entitled to the protection of the nonstatutory labor exemption. ${ }^{56}$ Relying on Justice White's view in United Mine Workers v. Pennington $^{57}$ that "collective bargaining agreements may violate the Sherman Act 'even though the mechanism for effectuating the purpose of the combination was an agreement on wages," "\$8 the Third Circuit found that "[a]lthough the [conspiring] contractors . . . would not be directly setting prices on commodities in the usual sense ...., they could nevertheless be conspiring to set a price on labor which would affect prices and margin of profit." ${ }^{\text {"30 }}$ Thus, TCU was part of an employers' conspiracy to eliminate competitors in various markets for construction services. Because of this predatory intent, the court held the unions' complaint legally sufficient.

The courts' reasoning in the sham-union cases suggests that a successful antitrust claim could be based upon a conspiracy among employers in a unionized product market to eliminate competitors by getting rid of the union representing their employees and thereby reducing their labor costs. An antitrust challenge to such employers' conduct extends the reasoning in Heat \& Frost Insulators by equating for antitrust purposes any and all means of destroying a union with the shamunion technique. Although the factual basis for such a challenge comes close to those in cases in which section 1 claims have been dismissed, ${ }^{80}$ that result can be avoided if the overall purpose of the employers' antiunion campaign is to reduce labor costs and eliminate competing employers, thereby impairing the competitive structure of a product market.

Whether allegations of that ultimate anticompetitive goal would sustain an antitrust challenge to an employers' anti-union campaign is now at issue in Seafarers International Union v. American Commercial Lines. ${ }^{\text {B1 }}$ The plaintiff, SIU, has alleged that the defendant employers conspired to eliminate competitors in the market for barging services along the Mississippi River and in the Gulf of Mexico. ${ }^{62}$ The alleged method employed was to eliminate SIU from the defendants' operations by, among other things, blacklisting all seamen registered at the union's hiring halls and encouraging employees to file decertification petitions with the National Labor Relations Board. ${ }^{63}$ The district court's ruling

ss Id. at 392 .

87 381 U.S. 657 (1965).

s8 483 F.2d at 392 (quoting Pennington, 381 U.S. at 663).

s. 483 F.2d at 392 .

So Supra notes $47-50$ and accompanying text.

${ }^{61}$ No. 80-1565 (E.D. La. Nov. 12, 1980) (granting stay pending NLRB order).

${ }^{62}$ Complaint at 8, Seafarers.

es Id. at 10-13. The complaint alleges that representatives of American Commercial Lines (ACL), National Marine Services (NMS), Dixie Carriers, and ACL's affiliated barging compa- 
on the defendants' motion to dismiss has been deferred pending an NLRB decision in associated unfair labor practice proceedings.

\section{Anticompetitive Acts Affecting Only a Labor Market}

Group boycotts and price-fixing, when carried out by buyers in a product market, are per se violations of section $1 .^{64}$ With respect to the purchase of one particular service-labor-such practices are known as blacklisting and wage-fixing, respectively. Are blacklisting or wagefixing therefore unlawful in themselves, without regard to their effects upon competition in a product market? ${ }^{65}$ The fundamental issue is whether section 1 prohibits employers' anticompetitive conduct affecting only a labor market.

nies, were all present at a meeting during which Kilroy, ACL's representative, presented a plan to eliminate competitors by undertaking an anti-union campaign against Seafarers, the collective bargaining representative of the barging companies' employees:

In or about November 1978, defendant Kilroy, representing himself to be an agent of [ACL's parent corporation], ACL and its defendant subsidiaries, and representatives of NMS and Dixie met in New Orleans. At that meeting, Kilroy proposed and urged a strategy for eliminating SIU from the operations of NMS and Dixie and ACL's defendant subsidiaries by drastically reducing its membership and its revenues, and undermining the goodwill and allegiance of seamen to SIU by demonstrating to the seamen in the area of dominance that SIU could not be relied upon as a source of job referrals or as an effective collective bargaining representative. He stated that the purpose of eliminating SIU was to reduce labor costs and other operating restraints caused by SIU in the area of dominance, and to enable the conspirators to capture an additional share of the market in that area from employers with SIU contracts. The tactics to implement the strategy Kilroy urged included but were not limited to:

(i) boycotting and blacklisting all seamen registered at SIU-operated hiring halls . . . and hiring seamen from non-union related sources;

(ii) terminating contributions to all existing joint union-managment employee benefit funds, such as pension and welfare funds for SIU seamen;

(iii) denying non-employee SIU representatives access to vessels aboard which were SIU members; and

(iv) inducing and encouraging employees to file petitions with the National

Labor Relations Board to decertify SIU as their collective bargaining representative.

The author serves as counsel to SIU in this case.

os See Northern Pac. Ry. v. United States, 356 U.S. 1, 5 (1958); see also supra text accompanying note 30 . Although most group boycott and price-fixing cases involve conduct by sellers of goods or services, the same conduct is equally unlawful when done by buyers. See, e.g., Mandeville Island Farms, Inc. v. American Crystal Sugar Co., 334 U.S. 219 (1948) (price-fixing); Anderson v. Shipowners' Ass'n, 272 U.S. 359 (1926) (group boycott); Eastern States Retail Lumber Ass'n v. United States, 234 U.S. 600 (1914) (group boycott).

os The Supreme Court has established that anticompetitive acts in or affecting a labor market-blacklisting, for example-may violate $\S 1$ if they are part of anticompetitive conduct affecting a product market. See, e.g., Radovich v. National Football League, 352 U.S. 445 (1957). Radovich had been blacklisted for signing a contract with the World Football League. The Court also has upheld $\S 1$ violations based upon labor market restraints that are in themselves lawful, but suppress competition in a product market. See, e.g., United Mine Workers v. Pennington, 381 U.S. 657 (1965); see also Nichols v. Spencer Int'l Press, 371 F.2d 332 (7th Cir. 1967) (employers agreed not to hire each other's employees for six months after termination); Union Girculation Co. v. FTC, 241 F.2d 652 (2nd Cir. 1957) (magazine subscription solicitation agencies agreed not to hire anyone who had worked for another such agency in the past year). 
In Amalgamated Clothing \& Textile Workers v. J.P. Stevens \& Co. ${ }^{66}$ the district court held that blacklisting and wage-fixing do not in themselves violate section 1 . Interpreting Apex and its progeny ${ }^{67}$ to require " some form of restraint upon commercial competition in the marketing of goods and services" "for a section 1 violation, ${ }^{68}$ and finding that neither blacklisting nor wage-fixing involved such restraint, the court held that the alleged blacklisting and wage-fixing " $\mathrm{d}[\mathrm{id}]$ not rise to the level of an anti-trust violation." 69 In the view of the district court and several commentators, ${ }^{70}$ Stone's use of the term "commercial competition" in Apex refers to the competitive structure of a product market only, not a labor market. In that view, Stone modified "competition" with the term "commercial" in order to refer only to transactions regarding goods and services between entrepreneurs.

But Stone's use of the phrase "commercial competition" in Apex is ambiguous. Under an alternative interpretation, it is "competition," not "commercial," that is the key word in the phrase. The question before the Court in Apex was whether preventing a shipment of goods in interstate commerce violated the Act. Stone concluded that it did not. $\mathrm{He}$ could have used "commercial competition" to distinguish between conduct that does or does not affect the competitive structure of a product market. The phrase "commercial competition" thus would have provided a principled distinction between the union's preventing the shipment of finished stockings, which Stone did not consider unlawful under section 1, and agreeing to fix the price of stockings or to apportion customers, which Stone indicated would violate section 1.

This latter interpretation of "commercial competition" is preferable for several reasons. First, it fits the facts of Apex. Stone found that the union's activities in fact had affected the product market for hosiery and yet were lawful. Thus, the distinction between anticompetitive acts affecting a product market and those affecting only a labor market was irrelevant to the issue before him. Any statements restricting the scope

66475 F. Supp. 482 (S.D.N.Y. 1979), vacated as moot, 638 F.2d 7 (2nd Cir. 1980).

${ }^{87}$ The district court in J.P. Stevens cited, inter alia, Prepmore Apparel v. Amalgamated Clothing Workers, 431 F.2d 1004 (5th Cir. 1970), cert. dismissed, 404 U.S. 801 (1971), Kennedy v. Long Island R.R., 319 F.2d 366 (2nd Cir.), cert. denied, 375 U.S. 830 (1963), and United Brick \& Clay Workers v. Junction City Clay Co., 158 F.2d 552 (6th Cir. 1942), as Apex's progeny. 475 F. Supp. at $489-90$.

${ }^{68} 475$ F. Supp. at $488-89$ (quoting Apex, 310 U.S. at 495).

69 Id. at 490 .

70 See, e.g., Cox, Labor and the Antitrust Laws-A Preliminary Analysis, 104 U. PA. L. REv. 252, 254-55 (1954); Handler, Labor and Antitrust: $A$ Bit of History, 40 ANTITRUST L.J. 233, 235 (1971); St. Antoine, Connell: Antitrust Law at the Expense of Labor Law, 62 VA. L. REV. 603, 606 (1976). But see 1 P. AREEDA \& D. TURNER, ANTITRUST LAW 202 (1978) ("employers agreeing on trade restrictions in the labor market are subject to the same antitrust sanctions as usual when collective bargaining is not involved"). 
of the Act to anti-competitive activities affecting only the product market would have been obiter dicta. More significantly, Stone's focus on the difference between activities that restrict competition in a market and those that do not is what distinguishes Stone's conclusion from that of the dissenters. ${ }^{71}$

Second, if Stone's observation had been meant to restrict section 1's scope to anticompetitive activities affecting only product markets, Stone's failure to discuss Anderson v. Shipowners Association ${ }^{72}$ would have been a glaring and inexplicable omission, particularly in view of Stone's efforts to discuss all the pertinent Supreme Court antitrust decisions. ${ }^{73}$ In Anderson almost all the owners and operators of American flag merchant vessels sailing along the Pacific Coast were members of the defendant Shipowners Association, which had established hiring halls with stringent procedures for supplying seamen to its members' vessels. If a seaman failed to follow these procedures and apply for work through the hiring hall, he was precluded from employment on an Association member's vessel. Anderson, a well-qualified, veteran seaman who had not complied with all the hiring hall procedures and therefore was denied such employment, brought a class-action suit on behalf of himself and other seamen, claiming that the employers' blacklisting violated section 1. The Supreme Court held that Anderson's complaint stated a valid section 1 claim. It seems unlikely that Stone would have failed to distinguish or expressly overrule Anderson, a case decided while he was on the Court, if he had subscribed to the view that the Act applies only to impairments of competition in a product market: Anderson would have been recent precedent to the contrary. ${ }^{74}$

Third, Stone's opinion relied on common law restraint-of-trade cases as an important determinant of section 1's meaning. ${ }^{75}$ One category of agreements held to be unlawful restraints of trade around 1890 were contracts in which an employee promised not to seek similar employment for what was deemed an unreasonable period of time follow-

71 See Apex, 310 IJ.S. at 522 (Hughes, C.J., dissenting).

22272 U.S. 359 (1926).

7s See Apex, 310 U.S. at 495 \& n.16, 500.

74 One contemporary commentator who believed that Apex restricted the Act to anticompetitive conspiracies affecting a product market acknowledged Apex's inconsistency with Anderson, but sought to resolve the contradiction by reinterpreting Anderson as a restraint on commercial competition because it was imposed by an agreement among commercial competitors. Cavers, Labor v. The Sherman Act, 8 U. CHI. L. REV. 246, 250-51 n.9 (1941). That resolution is untenable, because even though competing employers adopted the restraint in Anderson, the restraint itself was directed at and affected competition in the labor market only. Nothing in the facts of Anderson as stated by the Court indicates any effect on competition in the shipping industry along the Pacific Coast.

${ }^{78}$ See 310 U.S. at 497-501. 
ing termination of the current employment. ${ }^{76}$ State courts held those contractual provisions to be unenforceable, even though they restrained competition only in a labor market. ${ }^{77}$ Thus, if Stone had viewed the Act as limited to the impairment of competition in product markets, his view would have been inconsistent with one of the premises of his argument in Apex.

Even if Stone had intended to restrict the Act's application to conduct affecting the competitive structure of a product market, subsequent antitrust cases would have undermined that restriction. United States v. National Association of Real Estate Boards, ${ }^{78}$ a more recent Supreme Court decision, adopts a definition of "trade" under the Sherman Act that includes the labor of an employee. ${ }^{78}$ This holding can be reconciled with Apex only by adopting the view that "commercial competition" includes competition in a labor market, because an employee's sale of labor is "trade or commerce." cases have held that employers' joint conduct suppressing competition

${ }^{78}$ See generally Blake, Employee Agreements Not to Compete, 73 HaRV. L. REv. 625 (1960); Goldschmid, Antitrust's Neglected Stepchild: A Proposal for Dealing with Restrictive Covenants Under Federal Law, 73 CoLUM. L. REv. 1193 (1973).

${ }_{77}$ See, e.g., Lanzit v. J.W. Sefton Mfg. Co., 184 Ill. 326, 56 N.E. 393 (1900); Herreshoff v. Boutineau, 17 R.I. 3, 19 A. 712 (1890). Similarly, covenants binding persons not to engage in a competing business in any capacity, including as an employee, were held unenforceable. See, e.g., Garroll v. Giles, 30 S.C. 412 , 9 S.E. 922 (1889); Keeler v. Taylor, 53 Pa. 467 (1867); Lange v. Werk, 2 Ohio St. 519 (1853); Alger v. Thacker, 36 Mass. (19 Pick.) 51 (1837).

${ }^{78} 339$ U.S. 485 (1950).

79 In Real Estate Bds., the Court held that fixing the rate of commissions for real estate brokers' services violates $\S 3$ of the Sherman Act. Finding that the "critical question" it faced was "whether the business of a real estate agent is included in the word "trade'" as used in the Sherman Act, 339 U.S. at 489, the Court adopted Justice Story's broad definition of "trade," which had originated in a vastly different context:

[T] he word "trade" is often, and indeed generally, used in a broader sense, as equivalent to occupation, employment, or business, whether manual or mercantile. Wherever any occupation, employment, or business is carried on for the purpose of profit, or gain or a livelihood, not in the liberal arts or in the learned professions, it is constantly called a trade. Thus, we constantly speak of the art, mystery, or trade of a housewright, a shipwright, a tailor, a blacksmith, and a shoe maker, though some of these may be, and sometimes are, carried on without buying or selling goods.

Id. at 490-91 (quoting The Nymph, 18 F. Cas. 507 (C.C.D. Me. 1834) (No. 10,388)). Justice Story was interpreting the Coasting and Fishery Act of 1793, ch. 8, 1 Stat. 305 (current version codified in scattered sections of 46 U.S.C.). The Supreme Court previously had adopted Justice Story's definition of "trade" in Atlantic Cleaners \& Dyers v. United States, 286 U.S. 427, 434-37 (1932). Both of these cases arose under $\S 3$ of the Sherman Act, which is based on Congress's plenary power to govern the District of Columbia, rather than $\S 1$, which is based on the commerce clause. But the Supreme Court indicated that $\S 1$ should be read in pari materia with $\S 3$ when, in Goldfarb v. Virginia State Bar, 421 U.S. 773, 787 (1975), a $\S 1$ case, it relied on Real Estate Bds. in defining "trade or commerce."

Bo In 1890, when the Sherman Act was passed, the term "trade" included a person's business, calling, or means of livelihood. See Comment, Personal Services and the Antitrust Laws, 1 WAYNE L. REV. 124, 129 \& n.28 (1955); see also Standard Oil Co. v. United States, 221 U.S. 1, 51 (1911); United States v. Addyston Pipe \& Steel Co., 85 F. 271, 279-81 (6th Cir. 1898), modified and afTd, 175 U.S. 211 (1899). 
for the purchase of professional athletes' labor violates section $1 \mathbf{. 1}^{\mathbf{8 1}}$ Those cases, some of which do not discuss Apex at all, do not restrict section 1's scope to anticompetitive activities affecting a product market. $^{82}$ For example, in Flood v. Kuhn, ${ }^{83}$ the Supreme Court decision upholding baseball's exemption from the antitrust laws solely for historical reasons, dissenting Justices Douglas and Brennan would have denied the exemption and held that forbidding an employee, such as Flood, from practicing his profession violates section 1. Finally, although the vitality of Apex continues to be recognized, numerous lower federal courts have acknowledged in recent years that the Sherman Act extends to anticompetitive activities affecting only a labor market. ${ }^{84}$

If, then, Apex does not restrict section 1's scope to effects on a product market, the antitrust challenge in J.P. Stevens was wrongly dismissed, ${ }^{85}$ and claims against blacklisting and wage-fixing should be actionable under that section.

The conclusion that employer's blacklisting or wage-fixing may violate section 1 rests on the premise that the sale of labor is "trade or commerce." At first glance, that premise flies in the face of section 6 of

81 See, e.g., Smith v. Pro Football, Inc., 593 F.2d 1173 (D.C. Cir. 1978); Mackey v. National Football League, 543 F.2d 606 (8th Cir. 1976), cert. dismissed, 434 U.S. 801 (1977); Linseman v. World Hockey Ass'n, 439 F. Supp. 1315 (D. Conn. 1977) (granting preliminary injunction); Robertson v. National Baskeball Ass'n, 389 F. Supp. 867 (S.D.N.Y. 1975); Bowman v. National Football League, 402 F. Supp. 754 (D. Minn. 1975) (granting preliminary injunction); Kapp v. National Football League, 390 F. Supp. 73 (N.D. Cal. 1974), affd, 586 F.2d 644 (9th Cir. 1978), cert. denied, 941 U.S. 907 (1979); Blalock v. Ladies Professional Golf Ass'n, 359 F. Supp. 1260 (N.D. Ga. 1973); Denver Rockets v. All-Pro Management, 325 F. Supp. 1049 (C.D. Cal. 1971). Although these courts often describe the market affected by the defendants' unlawful conduct as "the market for players' services," professional athletes are as much "employees" under the National Labor Relations Act, 29 U.S.C. \$§ 151-169 (1976), and Labor Management Relations Act, 61 Stat. 136 (1947) (codified as amended in scattered sections of 29 U.S.C.) as are other, lower-paid and less famous wage laborers. Like other employees, they are represented for collective bargaining purposes by labor organizations. See Reynolds v. National Football League, 584 F.2d 280, 282 (8th Cir. 1978); Note, The Professional Athlete and the First Amendment: A Question of Judicial Intervention, 4 HOFSTRA L. REV. 417, 432 n.74 (1976). Since the players' services are merely a particular type of labor, the market for players' services is a labor market.

82 See, e.g., Mackey v. National Football League, 543 F.2d 606, 616-18 (8th Cir. 1976), cert. dismissed, 434 U.S. 801 (1977).

ss 407 U.S. 258, 287 \& n.2 (1972); see also Haywood v. National Basketball Ass'n, 401 U.S. 1204, 1205 (Douglas, Circuit Justice, 1971).

84 See, e.g., Ostrofe v. H.S. Crocker Co., 670 F.2d 1378, 1381 \& n.3 (9th Cir. 1982); Hennessey v. National Collegiate Athletic Ass'n, 564 F.2d 1136, 1150-51 (5th Cir. 1977); Newburger, Loeb \& Co. v. Gross, 563 F.2d 1057, 1081-83 (2d Gir.), cert. denied, 434 U.S. 1035 (1977) Bravman v. Bassett Furniture Indus., 552 F.2d 90, 101-03 (3d Cir.), cert. denied, 434 U.S. 823 (1977); Quinonez v. National Ass'n of Sec. Dealers, 540 F.2d 824, 828-29 (5th Cir. 1976); Cesnik v. Chrysler Corp., 490 F. Supp. 859, 864 (M.D. Tenn. 1980); Blank v. Preventative Health Programs, 504 F. Supp. 416, 418 (S.D. Ga. 1980); Baughman v. Cooper-Jarrett, Inc., 391 F. Supp. 671, 677 n.2 (W.D. Pa. 1975), af'd in part, remanded on other grounds, 530 F.2d 529 (3d Cir.), cert. denied, 429 U.S. 825 (1976); Jacobi v. Bache \& Co., 377 F. Supp. 86, 95-96 (S.D.N.Y. 1974), aft'd, 520 F.2d 1231 (2d Cir. 1975), cert. denied, 423 U.S. 1053 (1976); Cordova v. Bache \& Co., 321 F. Supp. 600, 604-05 (S.D.N.Y. 1970).

ss See supra text accompanying notes 66-70. 
the Glayton Act, the first sentence of which states that "[t]he labor of a human being is not a commodity or article of commerce."88 Whether that sentence means what it literally says is a question integrally related to the judicial and legislative history underlying the statutory labor exemption. That exemption, as well as section 6's meaning, is discussed in the next section of this Article.

\section{The Statutory Labor Exemption}

\section{A. Protection for Organized Labor}

The statutory labor exemption is the result of organized labor's efforts over twenty-five years to right the Supreme Court's wrong in Loewe v. Lawlor. ${ }^{87}$ By holding the Sherman $\mathrm{Act}^{88}$ applicable to labor organizations and their activities, the Court in Loewe legitimized and encouraged the federal judiciary's use of Sherman Act injunctions to regulate labor-management relations from the employers' perspective. The history of organized labor's efforts to obtain statutory relief from antitrust liability is well-known and can be summarized briefly. ${ }^{89}$

In 1914 Congress passed the Clayton Act, ${ }^{90}$ a major addition to the antitrust laws that contained two provisions designed to immunize labor organizations from antitrust liability in at least some respects. Section 6 provides:

The labor of a human being is not a commodity or article of commerce. Nothing contained in the antitrust laws shall be construed to forbid the existence and operation of labor . . . organizations, instituted for the purposes of mutual help, and not having capital stock or conducted for profit, or to forbid or restrain individual members of such organizations from lawfully carrying out the legitimate objects thereof; nor shall such organizations, or the members thereof, be held or construed to be illegal combinations or conspiracies in restraint of trade, under the antitrust laws. ${ }^{91}$

Section 20 prohibits federal courts from enjoining certain specified acts "involving or growing out of a dispute concerning terms and conditions of employment" and includes a catch-all clause making such acts law-

Bs 15 U.S.C. $\$ 17$ (1976).

87208 U.S. 274 (1908).

s8 15 U.S.C. $\S \S 1-7$ (1976).

so See generally Allen Bradley Co. v. Local Union No. 3, Int'l Bhd. of Elec. Workers, 325 U.S. 797, 801-06 (1945); F. FRANKFURTER \& N. GREENE, THE LABOR INJUNCTION (1930).

${ }^{20}$ Ch. 323,38 Stat. 730 (1914) (current version at 15 U.S.C. $\S \S 12-27,18$ U.S.C. $\S \S 402$, $660,3285,3691$, and 29 U.S.C. $\$ \S 52,53$ (1976)).

ol 15 U.S.C. $\$ 17$ (1976). 
ful, notwithstanding any other federal legislation. ${ }^{92}$ The labor movement was joyous at the passage of these provisions, believing that it had achieved its goal of freeing its economic weapons from injunctive and other restraints. ${ }^{93}$

The Supreme Court, however, quickly read section 6 as simply a restatement of pre-existing law, which provided that the mere existence of a labor organization did not violate the Act, thereby dashing organized labor's belief that section 6 was its "Magna Charta." the Court gutted the force of section 20 by holding that it only protected acts growing out of labor disputes between employees and their immediate employer.$^{95}$ As a result, although labor organizations themselves were not illegal and in some cases strikes also were not, secondary boycotts and, in many circumstances, strikes and picketing, remained subject to antitrust liability. ${ }^{86}$

Again organized labor sought redress from Congress. This wave of lobbying, politicking, and congressional hearings culminated in the

9229 U.S.C. $\$ 52$ (1976). That section states:

No restraining order or injunction shall be granted by any court of the United States, or a judge or the judges thereof, in any case between an employer and employees, or between employers and employees, or between employees, or between persons employed and persons seeking employment, involving, or growing out of, a dispute concerning terms or conditions of employment, unless necessary to prevent irreparable injury to property, or to a property right, of the party making the application, for which injury there is no adequate remedy at law, and such property or property right must be described with particularity in the application, which must be in writing and sworn to by the applicant or by his agent or attorney.

And no such restraining order or injunction shall prohibit any person or persons, whether singly or in concert, from terminating any relation of employment, or from ceasing to perform any work or labor, or from recommending, advising, or persuading others by peaceful means so to do; or from attending at any place where any such person or persons may lawfully be, for the purpose of peacefully obtaining or communicating information, or from peacefully persuading any person to work or to abstain from working; or from ceasing to patronize or to employ any party to such dispute, or from recommending, advising, or persuading others by peaceful and lawful means so to do; or from paying or giving to, or withholding from, any person engaged in such dispute, any strike benefits or other moneys or things of value; or from peaceably assembling in a lawful manner, and for lawful purposes; or from doing any act or thing which might lawfully be done in the absence of such dispute by any party thereto; nor shall any of the acts specified in this paragraph be considered or held to be violations of any law of the United States.

${ }^{93}$ See Gompers, Labor Not A Commodity, 21 AM. FEDERATIONIST 866 (1914), quoted in 51 CONG. REC. 16,340 (1914) (statement of Rep. Buchanan); see also Mason, The Labor Clauses of the Clayton Act, 18 AM. POL. SCI. REV. 489 (1924).

94 See Duplex Printing Press Co. v. Deering, 254 U.S. 443, 449-53 (1921); Paine Lumber Co. v. Neal, 244 U.S. 459 (1917). Gompers had described § 6's first sentence as the "Industrial Magna Charta upon which the working people will rear their structure of industrial freedom." Gompers, The Charter of Industrial Freedom: Labor Provisions of the Clayton Antitrust Law, 21 AM. FEDERATIONIST 957, 971-72 (1914).

${ }^{95}$ See Bedford Cut Stone Co. v. Journeymen Stone Cutters Ass'n, 274 U.S. 37 (1927); Duplex Printing Press Co. v. Deering, 254 U.S. 443 (1921).

${ }^{96}$ See Sayre, Labor and the Courts, 39 Yale L.J. 682, 695-704 (1930). 
Norris-LaGuardia Act of $1932,{ }^{97}$ which was intended primarily to prohibit the yellow-dog contract ${ }^{88}$ and to restrict the jurisdiction of federal courts to issue injunctions in labor disputes. Like section 20 of the Clayton Act, section 4 of the new law specified certain conduct which could not be enjoined if it involved or grew out of a labor dispute. ${ }^{99}$ The term "labor dispute" was broadly redefined to circumvent the Supreme Court's prior misinterpretation of section 20's scope. ${ }^{100}$ Section 5 of the new law prohibited federal courts from enjoining as an unlawful combination or conspiracy section 4 conduct done in concert. ${ }^{101}$

This time the Supreme Court got the message. In Milk Wagon Drivers Union v. Lake Valley Farm Products, ${ }^{102}$ the Court held that sections 4 and 5 of the Norris-LaGuardia Act prevent federal district

${ }^{97}$ Ch. 90, 47 Stat. 70 (1932) (current version at 18 U.S.C. $§ 3692,29$ U.S.C. $\S \S 101-115$ (1976)).

${ }^{98} A$ yellow-dog contract is one that binds an employee not to become or remain a member of a union. See 29 U.S.C. § 103 (1976).

${ }^{92} 29$ U.S.C. \& 104 (1976). That section states:

No court of the United States shall have jurisdiction to issue any restraining order or temporary or permanent injunction in any case involving or growing out of any labor dispute to prohibit any person or persons participating or interested in such dispute (as these terms are herein defined) from doing, whether singly or in concert, any of the following acts:

(a) Ceasing or refusing to perform any work or to remain in any relation of employment;

(b) Becoming or remaining a member of any labor organization or of any employer organization, regardless of any such undertaking or promise as is described in section 103 of this title;

(c) Paying or giving to, or withholding from, any person participating or interested in such labor dispute, any strike or unemployment benefits or insurance, or other moneys or things of value;

(d) By all lawful means aiding any person participating or interested in any labor dispute who is being proceeded against in, or is prosecuting, any action or suit in any court of the United States or of any State;

(e) Giving publicity to the existence of, or the facts involved in, any labor dispute, whether by advertising, speaking, patrolling, or by any other method not involving fraud or violence;

(f) Assembling peaceably to act or to organize to act in promotion of their interests in a labor dispute;

(g) Advising or notifying any person of an intention to do any of the acts heretofore specified;

(h) Agreeing with other persons to do or not to do any of the acts heretofore specified; and

(i) Advising, urging, or otherwise causing or inducing without fraud or violence the acts heretofore specified, regardless of any such undertaking or promise as is described in section 103 of this title.

100 See infra note 154.

10129 U.S.C. $§ 105$ (1976). That section states:

No court of the United States shall have jurisdiction to issue a restraining order or temporary or permanent injunction upon the ground that any of the persons participating or interested in a labor dispute constitute or are engaged in an unlawful combination or conspiracy because of the doing in concert of the acts enumerated in section 104 of this title.

102311 U.S. 91 (1940). 
courts from enjoining a secondary boycott, specifically rejecting the employers' argument that injunctions still could be issued against unions for Sherman Act violations. ${ }^{103}$

This was the legal context for Justice Frankfurter's classic formulation of the statutory labor exemption in United States v. Hutcheson. ${ }^{104}$ In that case the federal government sought to prosecute officers of the United Brotherhood of Carpenters under section 1 of the Sherman Act for a secondary boycott of certain employers in the course of a work assignment dispute with another union. The Court had held in Milk Wagon Drivers that such a secondary boycott could not be enjoined under the Norris-LaGuardia Act. The issue in Hutcheson, then, was whether action that is not within the scope of section 20 of the Clayton Act - such as a secondary boycott - could be the basis for a criminal conviction. Although the Norris-LaGuardia Act clearly protects such action against injunctive relief, it lacks section 20's catch-all clause immunizing the actors from criminal liability as well. ${ }^{105}$

Frankfurter's approach to the issue was to show, based on judicial and legislative history he well knew, ${ }^{108}$ that section 20 's catch-all phrase should be applied to all union activities specified in section 4 of the Norris-LaGuardia Act:

The Norris-LaGuardia Act reasserted the original purpose of the Clayton Act by infusing into it the immunized trade union activities as redefined by the later Act. In this light $\$ 20$ removes all such allowable conduct from the taint of being a "violation of any law of the United States," including the Sherman Law. ${ }^{107}$

That same judicial and legislative history counselled against the view that pre-Norris-LaGuardia-Act precedent ${ }^{108}$ applied to criminal, but not injunctive, proceedings against union activities. Frankfurter argued that it read Congress's intent in passing the Norris-LaGuardia Act too narrowly "to say that that which on the equity side of the court is allowable conduct may in a criminal proceeding become the road to

103 Id. at 100-03.

104312 U.S. 219 (1941).

108 See supra note 92 and accompanying text.

108 Frankfurter wrote the classic study of the judicial and legislative history leading up to the Norris-LaGuardia Act, see F. FRANKFURTER \& N. GREENE, supra note 7, and was actively engaged in the drafting of the law. Id. at 226 n.61.

107 Hutcheson, 312 U.S. at 236.

108 Duplex Printing Press Co. v. Deering, 254 U.S. 443 (1921). In Duplex the Court enjoined under the Act a nationwide secondary boycott instigated by the defendant union to aid in its attempt to organize plaintiffs factory. In reaching this result, the Court limited the scope of the term "labor dispute" in $\S 20$ of the Clayton Act to disputes over the terms and conditions of employment between employees and their immediate employers. Id. at 469-78. 
prison."109 $\mathrm{He}$ then concluded:

So long as a union acts in its self-interest and does not combine with non-labor groups, the licit and the illicit under $\S 20$ are not to be distinguished by any judgment regarding the wisdom or unwisdom, the rightness or wrongness, the selfishness or unselfishness of the end of which the particular union activities are the means. ${ }^{110}$

The significance of Frankfurter's opinion far transcends the resolution of the particular dispute in Hutcheson. His reasoning applies equally to treble damage antitrust actions against labor organizations, and his approach has shaped the contours of labor antitrust law to this day. Instead of first deciding whether the government's indictment (or the plaintiff's complaint) was legally sufficient under section 1, as Stone had done so comprehensively just a year before in Apex and did again in his Hutcheson concurrence, ${ }^{111}$ Frankfurter looked at whether the challenged conduct fell within the provisions of section 4 of the NorrisLaGuardia Act and therefore was immunized by section 20's catch-all phrase. If it did, then "it would be idle to consider the Sherman Law apart from the Clayton Act as interpreted by Congress. Cf. Apex Hosiery Co. v. Leader."112 Following Hutcheson, the predominant approach to labor antitrust cases has been to focus attention first on whether the union's challenged conduct is exempt and then, only if it is not, to consider whether that challenged conduct violates section 1 of the Act.

Thus, the statutory labor exemption is based substantially on the dialogue between Congress and the federal courts regarding the Act's applicability to trade union conduct. The focus of this dialogue was on the liability of unions, not employers. In contrast to the experience of labor organizations, employers had been the targets of few labor injunctions prior to the passage of the Norris-LaGuardia Act and apparently had engaged in no anti-injunction lobbying. It seems unlikely, therefore, that in passing the Clayton and Norris-LaGuardia Acts, Congress intended to relieve employers of any antitrust liability. ${ }^{113}$ This conclu-

\footnotetext{
${ }^{109}$ Hutcheson, 312 U.S. at 234-35.

110 Id. at 232 (footnote omitted).

111 Id. at 237.

112 Id. at 236.
}

113 This same general argument has met with only mixed success in injunctive actions under $\S 301$ of the Labor-Management Relations Act by unions against employers to preserve the status quo pending arbitration of a grievance. Some courts have held that the protections of the NorrisLaGuardia $\Lambda$ ct are unavailable to employers. See, e.g., Milk \& Ice Cream Drivers v. Gillespie Milk Prods. Corp., 203 F.2d 650 ( 6 th Cir. 1953); United Steel Workers v. Blaw-Knox Foundry \& Mill Machines, 319 F. Supp. 636, 640 (W.D. Pa. 1970); Textile Workers v. Aleo Mfg. Co., 94 F. Supp. 626 (M.D.N.C. 1950). But others have held that the Act protects employers in injunctive actions brought by unions. See, e.g., Amalgamated Transit Union v. Greyhound Lines, 550 F.2d 
sion is borne out by the specific legislative history underlying pertinent provisions of the two Acts.

\section{B. Section 6 of the Clayton Act Vis-a-Vis Employers' Conduct}

Does the first sentence of section 6 of the Clayton Act-"The labor of a human being is not a commodity or article of commerce"114_remove anticompetitive employers' conduct affecting only a labor market from the reach of the Sherman Act? Most courts considering that question have viewed section 6 as a "one-way street,"115 protecting labor unions but not protecting employers. ${ }^{116}$ Their conclusion is justified by an analysis of the pertinent legislative history.

The first sentence of section 6 was added to the Clayton Bill in the Senate, after the provision had passed the House. It was presented in the Senate Judiciary Committee's report as follows:

That nothing contained in the antitrust laws shall be construed to forbid the existence and operation of labor, agricultural, or horticultural organizations, instituted for the purpose of mutual help, and not having capital stock or conducted for profit, or to forbid or restrain individual members of such organizations from lawfully carrying out the legitimate objects thereof; nor shall such organizations, or the members thereof, be held or construed to be illegal combinations or conspiracies in restraint of trade under the antitrust laws. ${ }^{117}$

On September 1, 1914, Senator Cummins of Iowa proposed a substitute for section 6 that changed the language of the Committee's ver-

1237 (9th Cir.), cert. denied, 434 U.S. 837 (1977); International Union of Elec. Workers v. Wald Mfg. Co., 260 F. Supp. 824 (E.D. Ky. 1966); International Longshoreman \& Warehousemen v. Libby, McNeill \& Libby, 114 F. Supp. 249 (D. Hawaii 1953); Local 937, United Automobile Workers v. Royal Typewriters Co., 88 F. Supp. 669 (D. Conn. 1949); United Packing House Workers v. Wilson \& Co., 80 F. Supp. 563 (N.D. Ill. 1948). These holdings are distinguishable from the question of antitrust immunity. The Sherman Act, unlike $\$ 301$ of the Labor-Management Relations Act, pre-dates the Norris-LaGuardia Act. In addition, antitrust exemptions are to be narrowly construed, see, e.g., United States v. Philadelphia Nat'l Bank, 374 U.S. 321, 350-51 (1963).

11415 U.S.C. $\S 17$ (1976).

${ }^{126}$ Cordova v. Bache \& Co., 321 F. Supp. 600, 607 (S.D.N.Y. 1970).

116 See, e.g., California State Council of Carpenters v. Associated Gen. Contractors, 648 F.2d 527, 532-33 (9th Cir. 1980), cert. granted, 102 S. Ct. 998 (1982); Mackey v. National Football League, 543 F.2d 606, 616-18 (8th Cir. 1976), cert. dismissed, 434 U.S. 801 (1977); Robertson v. National Basketball Ass'n, 389 F. Supp. 867, 884-86 (S.D.N.Y. 1975); Cordova, 321 F. Supp. at 605-06; see also Cesnik v. Chrysler Corp., 490 F. Supp. 859, 865 (M.D. Tenn. 1980); Amalgamated Clothing \& Textile Workers v. J.P. Stevens \& Co., 475 F. Supp. 482, 488 (S.D.N.Y. 1979), vacated as moot, 638 F.2d 7 (2d Cir. 1980); 1 P. AREEDA \& D. TURNER, supra note 70, at 199. But see Nichols v. Spencer Int'l Press, 371 F.2d 332, 335-36 (7th Cir. 1967).

112 S. REP. No. 698, 63d Cong., 2d Sess. 59 (1914). It should be noted that $\S 6$ of the Clayton Act was numbered $\S 7$ of the Clayton Bill and it is referred to as $\S 7$ throughout the congressional debates. 
sion and incorporated provisions from what later became section 20 of the Clayton Act:

That the labor of a human being is not a commodity or article of commerce, and nothing contained in the antitrust laws shall be construed to forbid the existence and operation of labor organizations having for their objects bettering the conditions, lessening the hours, or advancing the compensation of labor, nor to forbid or restrain individual members of such organizations from carrying out said objects in a lawful way; nor shall said laws be construed to prevent or prohibit any person or persons, whether singly or in concert, from terminating any relation of employment or from ceasing to work or from advising or persuading others in a peaceful, orderly way, and at a place where they may lawfully be, either to work or abstain from working, or from withholding their patronage from a party to any dispute growing out of the terms or conditions of employment or from advising or persuading other wageworkers in a peaceful and orderly way so to do, or from paying or giving to or withholding from any person engaged in such dispute any strike benefits or other moneys or things of value, or from assembling in a peaceful and orderly way for a lawful purpose in any place where they may lawfully be, or from doing any act or thing which might lawfully be done in the absence of such dispute. Nothing contained in said antitrust laws shall be construed to forbid the existence and operation of agricultural, horticultural, or commercial organizations instituted for mutual benefit without capital stock and not conducted for the pecuniary profit of either such organization or the members thereof, or to forbid or restrain such members from carrying out said objects in a lawful way. ${ }^{128}$

In support of his proposed substitute, Cummins explained that he thought it preferable for section 6 to state the goals of labor organizations more precisely, to incorporate the other labor-related provisions of the bill, to add nonprofit mutual benefit commercial organizations to the list of protected organizations and, of most importance here, to distinguish labor from the commodities it produces. ${ }^{119}$

During this explanation, Cummins elaborated upon the importance of the distinction between labor and commodities:

[T] he labor of a human being is not a commodity or article of commerce. It is high time that we recognize the difference between the power of a man to produce something and the thing which he produces. Society has the right to regulate the sale and the transportation of the thing produced, but society has no right, according 
to our views of civilization, to say that a man who has the capacity to work shall work. He is free to either work or to abstain from working. $\mathrm{He}$ is free to persuade others to abstain from working. The thing in which he is dealing is not a commodity, and if we do not recognize the difference between the labor of a human being and the commodities that are produced by labor and capital and their transportations throughout the country we have lost the main distinction which warrants, justifies, and demands that labor organizations coming together for the purpose of bettering the conditions under which they work, of lessening the hours which they work, and of increasing the wages for which they work shall not be reckoned to be within a statute which is intended to prevent restraint of trade and monopoly. ${ }^{120}$

Cummins had made similar statements at other times during the Senate's deliberations on section $6 .{ }^{121}$

The debate on Cummins' proposed substitute centered primarily on whether it granted to labor organizations protection from antitrust liability as broad as that provided by the Committee's version of section 6. Committee members maintained that it did not. ${ }^{122}$ When a vote was taken on the Cummins amendment, it was rejected. ${ }^{123}$

Immediately thereafter, Senator Culbertson, Chairman of the Judiciary Committee, proposed that the first sentence of Cummins' substitute be added to the Committee's version of section 6 as its first sentence. Culbertson's proposal was adopted without debate. ${ }^{124}$

Section 6 of the Clayton Bill passed the Senate in that form. The Conference Report accepted the Senate amendments and the bill passed both Houses with section 6 unchanged. ${ }^{125}$ The only comments in the Senate about the first sentence of section 6 following Culbertson's amendment were those of Senators Nelson and Volstead (both of whom voted against the entire bill), who expressed concern that it might prevent Congress from legislating on behalf of laborers and labor organizations in the future. ${ }^{126}$ Congressman Webb, who explained to the House the Senate amendments adopted by the Conference Committee, stated that the first sentence of section 6 was "a mere legislative declaration or postulate" having no effect. ${ }^{127}$

Thus, the overall purpose of section 6 was to exempt labor organi-

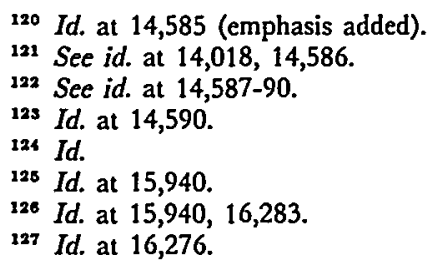


zations, inter alia, from antitrust liability for legitimate activities primarily affecting a labor market. The Cummins amendment was rejected in its entirety because it did not go far enough toward that goal. Therefore, the Senators adopting the first sentence of Cummins' amendment must have believed that it was consistent with the Senate's (and subsequently also the House's) purpose in enacting section 6. Presumably Culbertson proposed his amendment for the reason Cummins stated in support of the first sentence-because that sentence "warrants, justifies and demands" that labor organizations in and of themselves do not violate the Sherman Act. At no point in the Senate debates on section 6 did anyone suggest that its new first sentence would serve to exempt from antitrust liability anyone other than the organizations mentioned in the rest of the provision - that is, labor, agricultural, and horticultural organizations.

This legislative history clearly shows that section 6 was intended to protect labor organizations, not to exempt from antitrust liability all conduct affecting only a labor market on the ground that labor is not a commodity. Indeed, many courts have found such conduct violative of the antitrust laws. ${ }^{128}$ Twelve years after the passage of section 6 , when the Supreme Court in Anderson v. Shipowners' Association ${ }^{\mathbf{1 2 9}}$ held that it violated section 1 of the Sherman Act for employers to blacklist seamen who did not use their hiring hall, the Court did not even mention section 6 . It is only because nearly seventy years have elapsed since the Clayton Act became law and memories have faded that it is necessary to argue now what was crystal clear back then.

\section{Section 20 Of The Clayton Act and Sections 4, 5, and 13 of the Norris-LaGuardia Act Vis-a-Vis Employers' Conduct}

Employers may try to immunize their conduct by invoking the statutory labor exemption from the antitrust laws based on section 20 of the Glayton $\mathrm{Act}^{130}$ and the Norris-LaGuardia Act. ${ }^{131}$ The question whether the exemption extends to employers' conduct should be answered, if possible, by reference to congressional intent. This essentially was Frankfurter's approach when labor claimed the protection of the legislation in Hutcheson. ${ }^{132}$ Since the Court has not interpreted that

128 See supra note 84.

129272 U.S. 359 (1926).

$1 s 029$ U.S.C. $\$ 52$ (1976). See supra note 92 for entire text.

13129 U.S.C. $\$ \S 101-115$ (1976). Section 6 of the Glayton Act, 15 U.S.C. $\S 17$ (1976), is sometimes included as a component of the exemption. See, e.g., Associated Gen. Contractors, 648 F.2d at 532 .

132 See supra text accompanying notes 104-10. 
intent with respect to employers' immunity from antitrust liability, analysis must begin with the legislative history of the Norris-LaGuardia Act. That statute's proscription against injunctions covers a broader category of labor disputes than does section 20 of the Glayton Act, ${ }^{133}$ and the question of immunizing employers' conduct was posed in the debates on the Senate bill that became the Norris-LaGuardia Act. ${ }^{134}$

When that bill was presented to the Senate, it contained a statement of public policy explaining Congress' reason for passing the legislation. Such a statement was still uncommon in 1932 and there was some debate as to its necessity or propriety. ${ }^{135}$ Senator Norris, the author of the bill, defended the statement of policy as a guide to judicial interpretation that would "relieve . . . many of the difficulties which have heretofore existed when a court has been called upon to interpret the law"136 - obviously thinking of the Supreme Court's interpretation of the Clayton Act. ${ }^{137}$ The statement of policy, contained in section 2 of the bill, read as follows:

Whereas under prevailing economic conditions, developed with the aid of governmental authority for owners of property to organize in the corporate and other forms of ownership association, the individual unorganized worker is commonly helpless to exercise actual liberty of contract and to protect his freedom of labor, and thereby to obtain acceptable terms and conditions of employment, wherefore, though he should be free to decline to associate with his fellows, it is necessary that he have full freedom of association, selforganization, and designation of representatives of his own choosing, to negotiate the terms and conditions of his employment, and that he shall be free from the interference, restraint, or coercion of employers of labor, or their agents, in the designation of such representatives or in self-organization or in other concerted activities for the purpose of collective bargaining or other mutual aid or protection, therefore, the following definitions of and limitations upon the jurisdiction and authority of the courts of the United States are enacted. ${ }^{138}$

Senator Hebert, who authored the Senate Judiciary Committee's minority report on the bill, proposed a substitute to the Committee's version of section 2 :

19s See United States v. United Mine Workers, 330 U.S. 258, $269-71$ (1947).

134 S. 935, 72d Cong., 1st Sess. (1932).

135 See S. Rep. No. 163, 72d Cong., 1st Sess. 11-14 (1932); 75 CONG. REC. 4503 (1932) (statement of Sen. Norris); id. at 4626 (statement of Sen. Blaine); see also H.R. REP. No. 669, 72d Cong., 1st Sess. 3 (1932).

13675 CONG. REC. 4503 (1932).

237 See supra text accompanying notes 90-103.

$1 s 8$ S. REP. NO. 163, 72d Cong., 1st Sess. 5 (1932). 
Whereas under prevailing economic conditions a single employee is helpless in dealing with an employer, is ordinarily dependent on his daily wage for the maintenance of himself and his family, is unable to resist arbitrary and unfair treatment; and Whereas it is essential

(a) That he shall be free to associate with his fellow workers and to form unions which will afford him and them the opportunity to deal on a basis of equality with those by whom they are employed;

(b) That they may share equitably in the product of labor and capital;

(c) That both the employer and the employee shall have full freedom of association, self-organization, and designation of representatives of their own choosing, to negotiate the terms of employment free from any interference, restraint, or coercion in their efforts toward mutual aid or protection. ${ }^{38}$

Hebert explained, with particular reference to subsection (c), that his proposed substitute was designed to provide more "consideration" to employers than was provided in the Committee's statement of policy:

The declaration of policy in the minority bill tries to afford the same degree of consideration to the employer in his relations to his employee as it does to the employee in his relations with his employer. We have made no distinction in our declaraction of policy between one and the other, whereas in the declaration of policy contained in the majority bill there is very little, if any, reference to the consideration that is to be given to the employer in his relations with his employee. ${ }^{140}$

When the debate on Senator Hebert's substitute commenced, several Senate Judiciary Committee members spoke directly to the substitute's antitrust implications. Senator Walsh of Montana questioned what need there was to express support for employers' right to associate and whether the substitute's policy declaration "would not trench upon the acts enacted by Congress for curbing monopoly."141 Senator Norris raised the antitrust issue more explicitly: "[I]f we put in the other provision, the one the Senator has in here [Hebert's substitute], . . . these great combinations of wealth would say in the next lawsuit that this action of Congress relieved them from all responsibility of organization under the Sherman Anti-Trust Act."142 Senator King shared that concern:

13075 CONG. REC. 4677 (1932) (emphasis added).

140 Id. at 4678.

141 Id. at 4763.

142 Id. at 4764. 
The language employed is susceptible of the interpretation placed upon it by the Senator from Montana, and in its present form I would be afraid that it would be construed to mean that employers had the right to combine, and in such a manner as would be violative of either the Clayton or the Sherman antitrust laws. ${ }^{143}$

Senator Hebert responded by claiming that no violation of the antitrust laws by employers would be immunized by subsection (c). ${ }^{144}$

Following that colloquy, Hebert's substitute was defeated soundly. ${ }^{145}$ That vote, considered in light of the preceding debate's focus on employers' antitrust immunity, makes it quite clear that in passing the Norris-LaGuardia Act Congress had no intent to relieve employers of any liability under the antitrust laws.

The conclusion that neither section 20 of the Clayton Act nor the Norris-LaGuardia Act was intended to immunize employer conduct from antitrust liability is implicit in Allen Bradley Co. v. Local 3, International Brotherhood of Electrical Workers. ${ }^{148}$ There the Court held that Local 3 was liable under section 1 of the Sherman Act for combining with electrical contractors and manufacturers in New York City in order to eliminate competition from electrical equipment manufacturers who did not have a collective bargaining agreement with Local 3. Although the Court viewed the union's conduct as growing out of a labor dispute and thus falling within both section 20 and the Norris-LaGuardia Act, ${ }^{147}$ the Court imposed liability on Local 3 because "Congress never intended that unions could, consistently with the Sherman Act, aid non-labor groups to create business monopolies and to control the marketing of goods and services."148

The plaintiff electrical manufacturer in Allen Bradley did not sue the business group with whom Local 3 combined. The Court therefore rendered no holding on the employers' antitrust liability and did not address any immunity argument on their behalf. The Court did, however, indicate its view of the employers' conduct: "Quite obviously, this combination of business men has violated both $\S \S 1$ and 2 of the Sherman Act, unless its conduct is immunized by the participation of the union."149 The Court's statement that it was the union's participation that might have immunized the employers' conduct, not section 20 or the Norris-LaGuardia Act as applied directly to the employers, implies

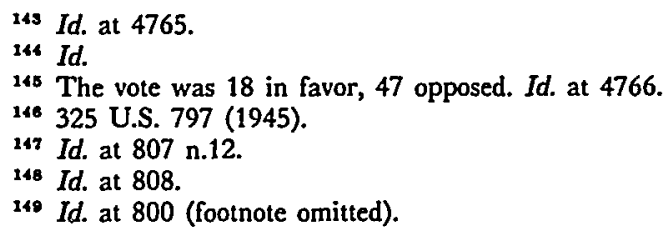


that the Court did not believe that those statutory provisions could protect employers' unilateral conduct from antitrust liability. In the Gourt's view, the union's conduct was not immune. If the Clayton and Norris-LaGuardia Acts, which were intended to immunize organized labor from antitrust liability, did not protect Local 3's conduct growing out of a labor dispute, they surely would not protect the same conduct if unilaterally undertaken by employers.

Just recently, the Supreme Court stated in H.A. Artists and Associates v. Actors' Equity Association that "a party seeking refuge in the statutory [labor] exemption must be a bona fide labor organization, and not an independent contractor."150 Although that statement was dictum, it reflects the holdings in a line of cases in which independent contractors and even entrepreneurs were accorded the protection of the statutory labor exemption only because they were considered to be a "labor group" in light of their particular relationship to a bona fide union and its members. ${ }^{161}$ The assumption underlying these cases is the conclusion the Court expressed as dictum in Actors' Equity.

Even if the Norris-LaGuardia Act did immunize employers' unilateral conduct, the scope of such an exemption would be narrowly limited by the terms of the Act. Section 4 is the basis for the antitrust immunity accorded in section 5 , and the only subsection in section 4 that refers to an employer's activities is $4(\mathrm{~b})$, which prohibits injunctions barring "any person or persons participating [in a labor dispute] from ... [b]ecoming or remaining a member ... of any employer organization."162 That provision merely immunizes from antitrust liability the formation and maintenance of multiemployer bargaining units; it does not immunize the collaborative acts of employers outside that structure, nor even the acts of such units when they do not serve the collective bargaining purposes for which they were intended. ${ }^{\mathbf{1 6 3}}$

Moreover, the statutory labor exemption applies only to conduct growing out of a "labor dispute" within the meaning of section 13 of the Norris-LaGuardia Act. ${ }^{154}$ Following American Medical Association

- ${ }^{280} 451$ U.S. 704, 717 n.20 (1981).

161 Compare American Fed'n of Musicians v. Carroll, 391 U.S. 99 (1968) (band leader and musicians are "labor group") with Los Angeles Meat \& Provision Drivers Union v. United States, 371 U.S. 94 (1962) (notwithstanding their membership in a common union, grease peddlers and drivers were not "labor group") and United States v. Women's Sportswear Mfg. Ass'n, 336 U.S. 460, 463-64 (1949) (stitching contractor is entrepreneur, not laborer, despite furnishing chiefly labor) and Columbia River Packers Ass'n v. Hinton, 315 U.S. 143 (1942) (dispute between independent fisherman and processor of fish over terms of sale not a "labor dispute").

${ }^{132} 29$ U.S.C. § $104($ b) (1976).

15s See Associated Gen. Contractors, 648 F.2d at 543-45.

18429 U.S.C. $\S 113(\mathrm{c})$ (1976). That section provides as follows:

The term "labor dispute" includes any controversy concerning terms or conditions of employment, or concerning the association or representation of persons in 
v. United States, ${ }^{155}$ it is highly unlikely that unilateral anticompetitive conduct by employers in and affecting a product market would be considered an outgrowth of a labor dispute. In that case the government brought a criminal prosecution against the American Medical Association (AMA), its District of Columbia and Illinois affiliates, and others for conspiring to prevent Group Health from providing medical care and hospitalization on a risk-sharing, prepayment basis. The AMA sought to protect the practices of its member doctors by preventing Group Health from hiring doctors as employees and from obtaining certain hospital services. The Court upheld the defendants' conviction, expressly rejecting their argument that their conduct was immunized by section 20 and the Norris-LaGuardia Act. In the Court's view, the dispute between the defendant associations and Group Health "was not one concerning terms and conditions of employment."158 The Court elaborated:

The petitioners [the defendants] did not represent present or prospective employes. Their purpose was to prevent anyone from taking employment under Group Health. They were interested in the terms and conditions of the employment only in the sense that they desired wholly to prevent Group Health from functioning by having any employes. Their objection was to its method of doing business. Obviously there was no dispute between Group Health and the doctors it employed or might employ in which petitioners were either directly or indirectly interested. ${ }^{187}$

In essence, the Court's reasoning was that the defendants-who were not labor organizations-were engaged in a dispute with a competing employer in a product market. The dispute was therefore not within the scope of section 13's definition of a "labor dispute."188

This same conclusion would apply, for example, to an employers' group boycott of union-signatory firms, such as that in Associated General Contractors. ${ }^{158}$ The employers' boycott of such firms is based, as in American Medical Association, on their "method of doing business," that is, bargaining collectively with a union. The absurdity of holding a

negotiating, fixing, maintaining, changing, or seeking to arrange terms or conditions of employment, regardless of whether or not the disputants stand in the proximate relation of employer and employee.

285317 U.S. 519 (1943).

158 Id. at 533.

${ }^{167}$ Id. at 536 (emphasis added).

${ }^{168}$ Cf. Jacksonville Bulk Terminals v. International Longshoremen's Ass'n, 102 S. Ct. 2673 (1982) (Norris-LaGuardia Act applies whenever employer-employee relationship is matrix of controversy).

189 California State Council of Carpenters v. Associated Gen. Contractors, 648 F.2d 527 (9th Cir. 1980), cert. granted, 102 S. Ct. 998 (1982). 
group boycott in a product market to be a labor dispute just because a union is the plaintiff in a lawsuit challenging the boycott's lawfulness is shown by considering whether the same argument could be raised if the boycotted union-signatory firms had been plaintiffs instead. In light of the Court's holding in American Medical Association, it would be untenable to maintain that the conspiring employers were engaged in a labor dispute with the boycotted plaintiffs. How, then, could such an argument succeed when the same conduct by the same employers is challenged by a different injured party - a union?

In sum, legislative history, statutory language, and Supreme Court precedent all point to one conclusion: with the exception of the formation and maintenance of multiemployer bargaining units, neither the Glayton Act nor the Norris-LaGuardia Act protects employers' conduct from antitrust liability.

\section{Standing}

\section{A. The Problems of Section 4 Standing}

The federal antitrust laws establish two private causes of action for violations of section 1 of the Sherman Act. An action for injunctive relief may be maintained under section 16 of the Clayton Act, which provides that "[a]ny person, firm, corporation, or association shall be entitled to sue for and have injunctive relief . . . against threatened loss or damage by a violation of the antitrust laws."160 A treble damage action may be brought under section 4 of the Clayton Act, which provides that "any person who shall be injured in his business or property by reason of anything forbidden in the antitrust laws may sue therefor . . . and shall recover threefold the damages by him sustained."161

It is generally recognized that sections 4 and 16 impose different standing requirements. ${ }^{162}$ A plaintiff seeking an injunction needs to satisfy only the usual requirements for such relief in a court of equity: ${ }^{\mathbf{1 6 3}}$ a threatened injury-in-fact will suffice. ${ }^{184}$ Since labor organizations would lose dues income, at least, from every legally sufficient section 1 claim described in Part $\mathrm{I},{ }^{165}$ they would have standing to sue for in-

16015 U.S.C. $\$ 26$ (1976).

16115 U.S.C. $\S 15$ (1976).

182 See, e.g., Hawaii v. Standard Oil Co., 405 U.S. 251, 260-64 (1972); Associated Gen. Contractors v. Otter Tail Power Co., 611 F.2d 684, 689 (8th Gir. 1979); Tugboat, Inc. v. Mobil Towing Co., 534 F.2d 1172, 1175 (5th Cir. 1976); In re Multidistrict Vehicle Air Pollution, 481 F.2d 122, 130-31 (9th Cir.), cert. denied, 414 U.S. 1045 (1973). But see Long Island Lighting Co. v. Standard Oil Co., 521 F.2d 1269, 1274 (2nd Cir. 1975), cert. denied, 423 U.S. 1073 (1976).

18315 U.S.C. $\S 26$ (1976).

164 See, e.g., Tugboat, 534 F.2d at 1174.

${ }^{185}$ See supra text accompanying notes 51-85. 
junctive relief based on each of those claims. The same conclusion applies to any employee who would lose a job or the opportunity to seek employment as a result of any of those alleged antitrust violations.

The standing issue is not so simple, however, with respect to treble damage actions. An award of treble damages is a particularly potent remedy for a section 1 violation, which can be expected to cause "ripples of harm to flow through the Nation's economy."166 Recognizing this, federal courts have felt the need to limit the expansive liability that would result from a literal reading of section $4 .^{167}$ Until the Supreme Court squarely addressed the question of a plaintiff's standing to sue for treble damages in Blue Shield v. McCready ${ }^{168}$ this year, the lower federal courts were forced to fashion their own limitations on a plaintiff's right to sue for treble damages. In that vacuum, the courts of appeals imposed a "legal causation" requirement upon a treble damage plaintiff's right to sue: in addition to the requirement of injury to business or property caused in fact by an antitrust violation, ${ }^{169}$ plaintiff's injury also must have been "legally caused" by the violation. ${ }^{170}$

Unfortunately, each court of appeals has adopted its own version of the legal causation requirement and some appellate courts have adopted more than one. The most common formulation is the "target area" test: to have standing under section 4 of the Clayton Act, the plaintiff must be foreseeably within "that area of the economy which is endangered by a breakdown of competitive conditions in [the] particular industry." 171 Other circuits have adopted the categorization approach, focusing on the relationship between the plaintiff and the alleged antitrust offender. ${ }^{172}$ Under this approach, plaintiffs are categorized into certain classes, such as lessees, employees, or stockholders; the court

${ }^{168}$ Blue Shield v. McCready, 102 S. Ct. 2540,2547 (1982).

187 See Ostrofe v. H.S. Grocker Co., 670 F.2d 1378, 1382-83 (9th Cir. 1982); Tugboat, 534 F.2d at 1174-75. See generally Berger \& Bernstein, An Analytical Framework for Antitrust Standing, 86 YALE L.J. 809, 810-13 (1977).

102 S. Ct. 2540 (1982).

188 See, e.g., Tugboat, 534 F.2d at 1175; see also Berger \& Bernstein, supra note 167, at 810-11. The Supreme Court has acknowledged this development. Hawaii v. Standard Oil Co., 405 U.S. 251, 262 n.14 (1972).

170 See Berger \& Bernstein, supra note 167 , at $810-11$.

171 Conference of Studio Unions v. Loew's, Inc., 193 F.2d 51, 53-54 (9th Cir. 1951), cert. denied, 342 U.S. 919 (1952); see also Pan-Islamic Trade Corp. v. Exxon Corp., 632 F.2d 539, 546-47 (5th Gir. 1980), cert. denied, 454 U.S. 927 (1981); In re Multidistrict Vehicle Air Pollution, 481 F.2d at 126-29; Calderone Enters. Corp. v. United Artists Theatre Circuit, 454 F.2d 1292, 1295 (2d Cir. 1971), cert. denied, 406 U.S. 930 (1972). See generally Berger \& Bernstein, supra note 167 , at $830-35$.

${ }^{172}$ See, e.g., Reibert v. Atlantic Richfield Co., 471 F.2d 727, 731 (10th Cir.), cert. denied, 411 U.S. 938 (1973); Volasco Prods. Co. v. Lloyd A. Fry Roofing Co., 308 F.2d 383, 394-95 (6th Cir. 1962), cert. denied, 372 U.S. 907 (1963); Productive Inventions Inc. v. Trico Prods. Corp., 224 F.2d 678, 679 (2d Cir. 1955), cert. denied, 350 U.S. 936 (1956); Loeb v. Eastman Kodak Co., 183 F. 704, 709 (3d Cir. 1910). See generally Berger \& Bernstein, supra note 167, at 820-30. 
determines whether a plaintiff has standing by referring to an established body of case law that applies to each category. ${ }^{173}$ Still other circuits have used a "zone of interest" test derived from administrative law to determine whether the plaintiff's injury arguably falls within the zone of interest the antitrust laws were designed to protect. ${ }^{174}$ And recently, at least two circuits have rejected each of these "bright line" tests for a more policy-based balancing approach. ${ }^{175}$

This divergence of standards has resulted in doctrinal chaos among the circuits - and sometimes even within a single circuit. ${ }^{176}$ In addition, the vagueness intrinsic to each of the standards has resulted in inconsistent decisions even among courts using the same standard. ${ }^{\mathbf{1 7 7}}$

The issue of standing under section 4 is further complicated by the closely related, but analytically distinct, concept of "antitrust injury" articulated in Brunswick Corp. v. Pueblo Bowl-O-Mat. ${ }^{178}$ Brunswick was an action brought for violation of section 7 of the Clayton Act, which proscribes mergers whose effect "may be substantially to lessen competition, or to tend to create a monopoly."178 That provision is intended to prevent anticompetitive effects before they occur. The defendant Brunswick, one of the two largest American manufacturers of bowling equipment, acquired and then operated certain bowling centers in competition with those owned by the plaintiffs. Seeking treble damages and other relief, the plaintiffs claimed that Brunswick's "deep pocket" would enable it to undertake predatory practices in a market of much less wealthy competitors. The jury found section 7 liability and the plaintiffs were awarded treble damages. The court of appeals remanded, but concluded that if the plaintiffs could show that the acquired bowling centers would have gone out of business but for Brunswick's actions, the plaintiffs would be entitled to treble damages based on their lost profits.

The Supreme Court disagreed. Justice Marshall, writing for a unanimous Court, pointed out that every merger, lawful or unlawful, adversely affects some persons, but that it would not serve the purposes

173 In re Multidistrict Vehicle Air Pollution, 481 F.2d at 127; Berger \& Bernstein, supra note 167 , at $820-830$.

174 See, e.g., California State Council of Carpenters v. Associated Gen. Contractors, 648 F.2d 527, 537-38 \& n.18 (9th Cir. 1980), cert. granted, 102 S. Ct. 998 (1982); Malamud v. Sinclair Oil Corp., 521 F.2d 1142, 1151-52 (6th Cir. 1975).

${ }_{178}$ See, e.g., Ostrofe, 670 F.2d 1378, 1383-86 (9th Cir. 1982); Bravman v. Bassett Furniture Indus., 552 F.2d 90, 99 (3rd Cir.), cert. denied, 434 U.S. 823 (1977).

${ }^{176}$ See Ostrofe v. H.S. Crocker Co., 670 F.2d at 1382 \& n.7. See generally Berger \& Bernstein, supra note 167 , at $819-45$.

${ }_{177}$ Ostrofe, 670 F.2d at 1383 \& n.7. See generally Berger \& Bernstein, supra note 167, at 840 n.139.

178429 U.S. 477 (1977).

17015 U.S.C. $\S 18$ (1976). 
of the antitrust laws to award damages for a merger unlawful under section 7 unless the injury sustained was the result of that which made the merger unlawful. ${ }^{180}$ The merger in Brunswick was unlawful because "deep-pocket" Brunswick had the potential for predatory pricing in the market for bowling services. But this was unrelated to the plaintiffs' loss of profits, since the plaintiffs would have suffered the same injury if the acquired bowling centers had been purchased by a smaller, less profitable company than Brunswick. Thus, concluded the Court, "if respondents [plaintiffs] were injured, it was not 'by reason of anything forbidden in the antitrust laws': while respondents' loss occurred 'by reason of' the unlawful acquisitions, it did not occur 'by reason of' that which made the acquisition unlawful."181

Justice Marshall then described the Court's holding in very broad language:

We therefore hold that for plaintiffs to recover treble damages on account of $\S 7$ violations, they must prove more than injury causally linked to an illegal presence in the market. Plaintiffs must prove antitrust injury, which is to say injury of the type the antitrust laws were intended to prevent and that flows from that which makes defendants' acts unlawful. The injury should reflect the anticompetitive effect either of the violation or of anticompetitive acts made possible by the violation. ${ }^{\mathbf{2} 2}$

This passage inaugurated the "antitrust injury" concept.

The precise meaning and applicability of this concept were unclear until the Court decided Blue Shield v. McCready. ${ }^{\mathbf{1 8 3}}$ Was it, as the language of Marshall's opinion suggests, something broader than the Court's holding that treble damages for injuries resulting from increased competition do not serve the purposes underlying section 4 and therefore may not be recovered? Did the concept of antitrust injury apply to violations of antitrust laws other than section 7 of the Clayton Act?184 What was the relationship between "standing" and "antitrust injury"? 185

In short, the question whether a plaintiff has standing to sue for treble damages under section 4 traditionally has been difficult to answer. In 1982, for the first time, the Supreme Court confronted that question head-on.

180429 U.S. at 489.

181 Id. at 488.

${ }^{182}$ Id. at 489 (emphasis in original).

183102 S. Ct. 2540 (1982).

184 See Ostrofe, 670 F.2d at 1386 \& n.22 (citing cases).

180 See id. at 1386 \& n.23; see also Page, Antitrust Damages and Economic Efficiency: An Approach to Antitrust Injury, 47 U. CHI. L. REV. 467, 497-500 (1980). 


\section{B. Blue Shield v. McCready}

In 1978 Carol McCready commenced a class action on behalf of herself and other Blue Shield subscribers who had paid fees for psychotherapy performed by a psychologist. These fees had not been reimbursed by Blue Shield. The complaint alleged that Blue Shield and the Neuropsychiatric Society of Virginia, an organization of Virginia psychiatrists, had conspired to exclude psychologists from the market for psychotherapy services in Virginia. In furtherance of that conspiracy, McCready alleged, Blue Shield had refused to reimburse its subscribers for psychotherapy performed by psychologists, while providing reimbursement for comparable treatment by psychiatrists. The complaint further alleged that Blue Shield's deliberate failure to reimburse payments to psychologists constituted a group boycott in violation of section 1 of the Sherman Act and injured subscribers' property, entitling subscribers like Carol McCready to an award of treble damages under section 4 of the Glayton Act. ${ }^{186}$

Adopting the "target area" test for section 4 standing, ${ }^{187}$ the district court dismissed the complaint on the ground that McCready lacked standing: because the goal of the alleged boycott was to exclude psychologists from the psychotherapy market, the sector of the economy competitively affected consisted of those psychologists in the psychotherapy market, not unreimbursed Blue Shield subscribers. ${ }^{188}$ The Fourth Circuit reversed, holding that Blue Shield's failure to reimburse caused McCready an "immediate and direct" property loss. ${ }^{189}$ In concluding that McCready had standing, the appellate court pointed out that the policies underlying the "target area" test were inapplicable to McCready's claim: since McCready already had paid her psychologist his fee, her damages were not speculative or difficult to prove and there was no danger of a duplicative recovery. ${ }^{180}$

The Supreme Court affirmed, five to four. Writing for the Court, Justice Brennan avoided using any of the talismanic legal causation formulations established by the courts of appeals, adopting instead a policy-based approach to the question of McCready's standing to sue. Noting section 4's broad and unqualified language, Congress's " 'expansive remedial purpose in enacting $\S 4, "$, and the broad scope given section 4 in recent Supreme Court decisions, ${ }^{191}$ Brennan stated the ma-

188 See McCready, 102 S. Ct. at 2543-44.

187 See supra text accompanying note 171 .

$188102 \mathrm{~S}$. Ct. at 2544.

189 McCready v. Blue Shield, 649 F.2d 228, 231 (4th Cir. 1981).

100 Id. at 231-32.

191 McCready, 102 S. Ct. at 2545 (quoting Pfizer, Inc. v. India, 434 U.S. 308, 313-14 
jor premise of his opinion: "in the absence of some articulable consideration of statutory policy suggesting a contrary conclusion in a particular factual setting, we have applied $\S 4$ in accordance with its plain language and its broad remedial and deterrent objectives." ${ }^{182}$ Thus, Brennan suggested, a plaintiff whose injury fell within the literal language of section 4 and whose recovery of treble damages would serve the compensatory and deterrent policies underlying the provision presumptively would have standing to sue for treble damages. Brennan then identified "two types of limitation on the availability of the $\S 4$ remedy," the risk of duplicative recoveries and the remoteness of the injuries from the antitrust violation. ${ }^{193} \mathrm{He}$ further defined two elements of the remoteness limitation:

(1) . . . the physical and economic nexus between the alleged violation and the harm to the plaintiff, and, (2) more particularly, ... the relationship of the injury alleged with those forms of injury about which Congress was likely to have been concerned in making defendant's conduct unlawful and in providing a private remedy under $\S 4 .{ }^{194}$

This second element, of course, echoes the concept of antitrust injury articulated in Brunswick Corp. v. Pueblo Bowl-O-Mat. ${ }^{195}$

Brennan agreed with the circuit court that McCready's suit posed no risk of duplicative recoveries. Since the psychologist had been paid, he could not also claim damages. ${ }^{186}$ Moreover, since the amount of the reimbursement due $\mathrm{McCready}$ could be determined to the penny, there was no problem of speculative or abstract damages. ${ }^{197}$

Consistent with the district court's opinion, the defendants argued that McCready's injury was too remote from the alleged violation, because the alleged conspiracy was directed at psychologists in the psychotherapy market, not Blue Shield subscribers. ${ }^{188}$ Brennan rejected this argument, which would have limited the class of proper plaintiffs to psychologists, because " $[t]$ he availability of the $\S 4$ remedy . . . is not a question of the specific intent of the conspirators."189 In his view, McCready's injury was inextricably intertwined with the alleged violation, since it was the means to the conspirators' end:

(1978)).

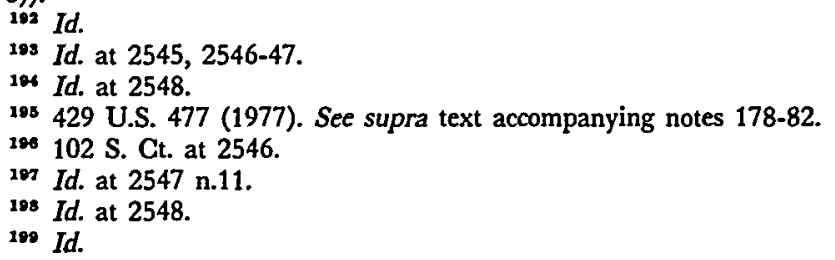


Denying reimbursement to subscribers for the cost of treatment was the very means by which it is alleged that Blue Shield sought to achieve its illegal ends. The harm to McCready and her class was clearly foreseeable; indeed, it was a necessary step in effecting the ends of the illegal conspiracy. ${ }^{200}$

Relying on language in Brunswick that in order to constitute an antitrust injury "[ $\mathrm{t}] \mathrm{he}$ injury should reflect the anticompetitive effect either of the violation or of anticompetitive acts made possible by the violation," the alleged conspirators also argued that McCready's injury was too remote because it did not reflect the anticompetitive effect of the alleged boycott against psychologists. ${ }^{201}$ Regardless of whether McCready's injury was a consequence of a lessening of competition in the market for psychotherapy services, Justice Brennan did not read Brunswick so expansively: despite its language, Brunswick did not require plaintiff's injury to reflect the antitrust violation's anticompetitive effect. In his view, since McCready's injury was a consequence of acts in furtherance of the alleged antitrust conspiracy, her injury " "flow[ed] from that which [made] defendants' acts unlawful' within the meaning of Brunswick, and [fell] squarely within the area of congressional concern."202

Justice Rehnquist's dissent, joined by Chief Justice Burger and Justice O'Connor, took issue with the majority primarily on this last point. According to Rehnquist, the majority's view that McCready's injury was not too remote because her injury was "a necessary step in effecting a conspiracy to place third parties at competitive disadvantage" was foreclosed by the antitrust injury concept in Brunswick. ${ }^{203}$ Rehnquist interpreted Brunswick to require that McCready's injury be the type of harm that made the challenged practice illegal. ${ }^{204}$ Therefore, Rehnquist argued, plaintiffs do not suffer antitrust injury unless they can show that the challenged practice is illegal with regard to its effect upon them. ${ }^{205}$ McCready lacked standing, in Rehnquist's view, because she did not allege that the challenged boycott had any anticompetitive effect on her, as opposed to its effect on psychologists performing psychotherapy. ${ }^{208}$

Justice Stevens dissented on the ground that McCready had suffered no injury to her property because of Blue Shield's reimbursement

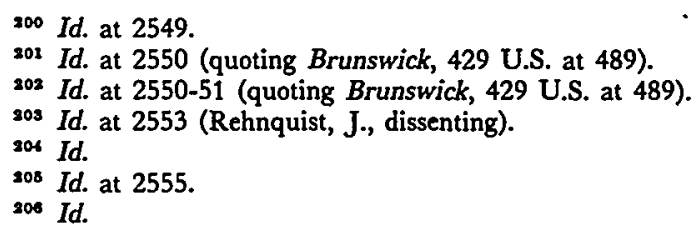


practice: since McCready presumably knew that she would not be reimbursed for psychotherapy by a psychologist and yet she still sought psychotherapy by her psychologist, she must have "received in exchange psychotherapeutic services that presumably were worth the [unreimbursed] payment."20z

The major virtue of Justice Brennan's McCready opinion is the adoption of a policy-based approach to section 4 standing, integrating pre-existing legal causation formulations and the antitrust injury concept. As some courts of appeals and commentators have recognized, ${ }^{208}$ a policy-based approach offers the possibility of a coherent body of standing decisions - a possibility apparently unattainable using any of the "bright line" legal causation tests. While adopting, in essence, a presumption that plaintiffs have standing if their injuries fall within the literal language of section $4-$ and if allowing recovery would serve the statute's compensatory and deterrent purposes - Brennan's opinion identifies at least some of the countervailing policies. ${ }^{209}$ Moreover, $\mathrm{Mc}$ Cready clarifies several of the ambiguities inherent in Brunswick. The antitrust injury concept is not limited solely to violations of section 7 of the Clayton Act, but plays a part in evaluating any antitrust injury's remoteness for standing purposes. And Marshall's broad language in Brunswick that the plaintiff's injury should "flow from that which makes defendant's acts unlawful"210 does not require that a section 4 plaintiff's injury be caused by the anticompetitive effect of the challenged conduct; an injury resulting from the means used to effectuate an anticompetitive end enables the injured party to sue for treble damages. ${ }^{211}$

Brennan's opinion suffers, however, from some major ambiguities of its own. First, some of the countervailing policy limitations are vaguely described. What are "speculative, abstract or impractical damage theories"?212 What is the "physical . . . nexus between the alleged [antitrust] violation and the harm to the plaintiff"?213 How does one identify "those forms of injury about which Congress was likely to have been concerned in making defendant's conduct unlawful"? ${ }^{214}$ Second,

207 Id. at 2556 (Stevens, J., dissenting).

208 See, e.g., Ostrofe 670 F.2d at 1383-84; Berger \& Bernstein, supra note 167, at 840-83.

200 The countervailing policies Justice Brennan identified were those acknowledged in prior Supreme Court cases. See McCready, 102 S. Ct. at 2545. There is no indication in his opinion that the policies identified were meant to be the only countervailing policies, and the above-cited language suggests the contrary.

210429 U.S. at 489.

211 McCready, 102 S. Ct. at 2549-52.

212102 S. Ct. at 2547 n.11.

213 Id. at 2548.

214 Id. 
Brennan does not indicate the precise relationship among the factors relevant to section 4 standing. For example, what if there is no risk of duplicative recovery or speculative damages, but the plaintiff's injury is "remote"? Does remoteness in itself vitiate an injured party's status as a treble damage plaintiff? Or, is that policy limitation somehow balanced against the policies and factors favoring that party's right to treble damages?

Moreover, Brennan's opinion provides only very limited guidance as to the most common issue arising in antitrust standing cases whether the plaintiff's injury is too remote. Brennan's conclusion that McCready's injury was not too remote rested on the fact that the type of injury she suffered was the means to the conspirators' ultimate goal. ${ }^{215}$ This is a rather unusual fact pattern. In most antitrust standing cases, the question is at what point in the chain of events caused by the defendant's initial act does a plaintiff's injury become too remote. ${ }^{216}$ None of the opinions in $M c$ Cready prescribes a test for answering that question, and Brennan's express refusal to endorse any of the appellate courts' legal causation formulations only postpones that decision. ${ }^{\mathbf{2 1 7}}$

\section{G. Section 4 Standing for Organized Labor}

Before applying the policy-based standing approach adopted in McCready to the antitrust claims discussed in Part $I,{ }^{218}$ it is worth observing that in the last ten years organized labor often has been successful in asserting standing under section 4. The carpenters unions were held to have standing to sue for treble damages resulting from the group boycott in Associated General Contractors. ${ }^{219}$ In Radovich v. National Football League, ${ }^{220}$ a professional football player was held to have stated a claim against the League for blacklisting him as part of a conspiracy to destroy a competing football league, suggesting that unionized employees would have section 4 standing in at least some antitrust cases involving unlawful conduct affecting a product market. The plaintiff labor organizations were accorded standing in the sham-union cases, as were the union members who lost work opportunities with the

215 Id. at 2548-49.

s16 See, e.g., California State Council of Carpenters v. Associated Gen. Contractors, 648 F.2d 527, 536-39 (9th Cir. 1980), cert. granted, 102 S. Ct. 998 (1982).

217102 S. Cit. at 2547 n.12.

218 See supra text accompanying notes 51-85.

219 California State Council of Carpenters v. Associated Gen. Contractors, 648 F.2d 527, 536-39 (9th Cir. 1980), cert. granted, 102 S. Ct. 998 (1982). See supra text accompanying notes 13-14.

130352 U.S. 445 (1957). 
defendant employers as a result of the "sweetheart agreements."221 The professional athlete cases and others establish that an injured employee has standing to sue for damages resulting from unlawful employers' conduct affecting a labor market. ${ }^{222}$ Although labor organizations cannot sue in a representative capacity for treble damages on behalf of their members, ${ }^{223}$ those members can bring a class action in their own right. ${ }^{224}$

Under a policy-based standing approach, organized labor should be just as successful. For example, blacklisted employees or employees whose wages were reduced as a result of a wage-fixing conspiracy should have section 4 standing to challenge the lawfulness of such labor market conduct. The employees' loss of jobs, work opportunities, or wages would be compensable injury to their business and property, and their damages could be estimated with sufficient precision so as not to be speculative. ${ }^{225}$ Moreover, as the direct and intended victims of such unlawful concerted action, those employees would be well-suited to deter such violations by bringing suit. The limitations on section 4 standing articulated in McCready would not apply. Since the employees would be competitors in the market affected by the illegal conduct, their injury would be direct, not remote, and there would be no risk of duplicative recoveries.

Since individual employees often lack the resources to finance an

231 Compare Tugboat, Inc. v. Mobile Towing Co., 534 F.2d 1172, 1176-77 (5th Cir. 1976) (employees have standing only when they themselves are targets of conspiracy, e.g., when defendants conspire to keep union members off job sites) with Carpenters Dist. Council v. United Contractor's Ass'n, 484 F.2d 119, 121-22 (6th Cir. 1973), modified, 539 F.2d 1092 (6th Cir. 1976) and International Ass'n of Heat \& Frost Insulators v. United Contractors Ass'n, 483 F.2d 384, 397 (3d Cir. 1973), modified, 494 F.2d 1353 (3d Cir. 1974) (employees have standing when their employers are targets of conspiracy, where allocation of loss between employer and employees is possible).

${ }^{222}$ See, e.g., Ostrofe v. H.S. Crocker Co., 670 F.2d 1378, 1381-82 (9th Cir. 1982); Hennessey v. National Collegiate Athletic Ass'n, 564 F.2d 1136, 1147-48 (5th Cir. 1977); Bravman v. Bassett Furniture Indus., 552 F.2d 90, 95-96 (3d Cir.), cert. denied, 434 U.S. 823 (1977); Mackey v. National Football League, 543 F.2d 606, 616-17 (8th Cir. 1976), cert. dismissed, 434 U.S. 801 (1977); Linseman v. World Hockey Ass'n, 439 F. Supp. 1315, 1320 (D. Conn. 1977); Robertson v. National Basketball Ass'n, 389 F. Supp. 867, 880 (S.D.N.Y. 1975).

${ }_{223}$ See, e.g., NAACP v. New York Clearing House Ass'n, 431 F. Supp. 405, 410 \& n.26 (S.D.N.Y. 1977) and cases cited therein; see also Associated Gen. Contractors v. Otter Tail Power Co., 611 F.2d 684, 689 n.5 (8th Cir. 1979) and cases cited therein; Amalgamated Clothing \& Textile Workers v. J.P. Stevens \& Co., 475 F. Supp. 482, 488 n.5 (S.D.N.Y. 1979), vacated as moot, 638 F.2d 7 (2d Cir. 1980); Cordova v. Bache \& Co., Inc., 321 F. Supp. 600, 604 (S.D.N.Y. 1970).

${ }_{224}$ See, e.g., Anderson v. Shipowners Ass'n, 272 U.S. 359 (1926); J.P. Stevens, 475 F. Supp. at 488 n.5; Cordova v. Bache \& Co., 321 F. Supp. 600, 604-05 (S.D.N.Y. 1970).

${ }^{225}$ The Court in $M c C r e a d y$ noted that "the feasibility and consequences of implementing particular damages theories may . . . be considered in determining who is entitled to prosecute an action brought under $\S 4$. . . . It may therefore be appropriate to consider whether a claim rests at bottom on some abstract conception or speculative measure of harm." $102 \mathrm{~S}$. Ct. at 2546-47 n.11. 
antitrust lawsuit, they may resort to class actions or request assistance from their union. A labor organization conceivably could function as class representative for a class of its member-employees. ${ }^{226}$ In addition, labor organizations might well have standing to sue for treble damages based on their own injuries. For example, when employees are blacklisted because of their union membership, the union may be able to prove a loss of dues income or an impairment of its ability to represent employees and to attract new members. Allowing unions to seek treble damages for such losses would serve the compensatory and deterrent purposes underlying section $4,{ }^{227}$ especially since blacklisted employees may not have the financial resources or motivation to sue and therefore antitrust violators otherwise might go unpunished.

The standing limitations most clearly implicated in such suits brought by unions are the risks of duplicative recoveries and speculative damage awards. Because dues income derives from employees' wages, a blacklisting employer who pays a blacklisted employee three times his lost wages in damages and also pays a union three times its lost dues income is subjected to duplicative recovery of a portion of the employees' wages. This risk can be avoided, however, whenever it is possible to allocate damages so that the employer pays the blacklisted employee treble damages for that portion of his lost wages which is not siphoned off for union dues and pays the union threefold its loss of dues income. This sort of allocation is easy to perform whenever the amount of union dues bears a fixed relationship to wages earned. Such allocation would also be consistent with $M c$ Cready, since the Supreme Court precedent establishing the risk of duplicative recoveries as a legitimate section 4 standing limitation expressly contemplates an exception for situations in which allocation of damages is possible. ${ }^{228}$

220 Unions serve as class representatives in title VII cases. See, e.g., International Woodworkers v. Georgia-Pacific Corp., 568 F.2d 64 (8th Cir. 1977); Local 194, Retail, Wholesale and Dep't Store Union v. Standard Brands, Inc., 540 F.2d 864 (7th Cir. 1976).

${ }^{237}$ See $M c$ Gready, 102 S. Ct. at 2545.

228 In support of the countervailing policy against the risk of duplicative recoveries, the Court in McCready cited Illinois Brick Co. v. Illinois, 431 U.S. 720 (1977), and Hanover Shoe v. United Shoe Mach., 392 U.S. 481 (1968). 102 S. Ct. at 2546. In Hanover Shoe, the Court held that an antitrust defendant could not mitigate its obligation to pay damages arising from illegal overcharges to the plaintiff, a direct purchaser, by demonstrating that the plaintiff had "passed on" the cost of such overcharges to consumers. 392 U.S. at 488-89. Conversely, the Court in Illinois Brick held that consumers and other indirect purchasers in most instances lack antitrust standing to sue a producer for injury passed on to them by a direct purchaser. 431 U.S. at 729 36. By proscribing the use of "passing-on" theory, both defensively (as in Hanover Shoe) and offensively (as in Illinois Brick), the Court sought, inter alia, to prevent duplicative recoveries by indirect and direct purchasers resulting from the same illegal overcharge. The Court in Hanover Shoe, however, recognized an exception to its general rule, applicable to situations involving "costplus" contracts. Under such agreements there is little danger of duplicative recovery because the exact amount of the overcharge passed on to the indirect purchaser may be determined and, accordingly, damages may be allocated between indirect and direct purchasers. See Hanover Shoe, 
The problem of speculative damage awards, however, may bar standing in many cases in which a union claims treble damages for injury to its ability to represent employees and organize workers, unless an event can serve to measure the extent of the injury. For example, if it could be demonstrated that blacklisting led to decertification of a union as the exclusive bargaining representative of the blacklisting employers' employees, the union's injury to its ability to represent employees - its loss of membership and thus of income from that bargaining unit - probably could be documented with sufficient precision to avoid being barred as speculative. Proving such a loss would not be very different from proving a business entity's loss of profits, a common measure of a corporation's antitrust injury. ${ }^{229}$

Remoteness of the union's injury is also a problem. The union's injury - loss of dues and fees - would be derivative of its members' loss of wages and thus one step removed from the initial impact of the antitrust violation. McCready dictates no conclusion about whether such injury would be too remote, since the opinion addressed the remoteness issue in very different factual circumstances. It would be consistent with $M c C r e a d y$, however, to analogize the remoteness issue to the tort concept of proximate cause. ${ }^{230}$ The point in the causal chain beyond which treble damages could not be recovered would then be defined by the foreseeability of the injury, a concept underlying both proximate cause ${ }^{231}$ and one version of the target-area test for antitrust standing. ${ }^{232}$ In fact, Brennan himself obliquely uses foreseeability as a yardstick in concluding that McCready's injury was not too remote. ${ }^{23 s}$

Antitrust lawsuits in which the plaintiffs are labor organizations or unionized employees challenging unlawful conduct in a product market present the most difficult standing problems. Although the risks of duplicative recoveries and speculative damages may be involved in some such suits, the limitation most obviously militating against section 4 standing for plaintiffs in product-market-based lawsuits is remoteness. Unions and unionized employees are at least one step removed from the antitrust violations because an anticompetitive purpose or effect vis-a-vis one or more business entities in the relevant product market is that which makes the challenged conduct unlawful. The injury to

392 U.S. at 494; see also Berger \& Bernstein, supra note 167, at 862 .

${ }_{220}$ See, e.g., Bigelow v. RKO Radio Pictures, Inc., 327 U.S. 251, $260-63$ (1946); Greyhound Computer Corp., v. International Business Machines Corp., 559 F.2d 488, 505 (9th Cir. 1977), cert. denied, 434 U.S. 1040 (1978).

${ }^{230}$ See $M c C r e a d y, 102$ S. Ct. at 2548 \& n.13.

231 See, e.g., W. PROSSER, HANDBOOK OF THE LAW OF TORTS $\S 43$ (4th ed. 1971). 1964).

${ }^{232}$ See, e.g., Twentieth Century Fox Film Corp. v. Goldwyn, 328 F.2d 190, 220 (9th Cir.

$28 s$ See 102 S. Ct. at 2549. 
the union or unionized employees is, at least in one sense, derivative of the injury to the business entities competing in the relevant market.

But $M c C r e a d y$ makes it clear that a party suffering derivative injuries still may have section 4 standing. Just as Carol McCready had standing even though she was not a competitor in the psychotherapy market, ${ }^{234}$ unions and unionized employees might have section 4 standing even though they are not competitors in a product market. Although the Court in McGready surely did not chart with precision or completeness the contours of the remoteness limitation, it did provide some illumination. Justice Brennan found, for example, that McCready's injury was not too remote because it was "the very means by which it is alleged that Blue Shield sought to achieve its illegal ends."2ss The injuries suffered by the plaintiff unions in the shamunion cases $^{236}$ and Seafarers ${ }^{237}$ are similar to McCready's: elimination of the unions was the means by which the defendant employers sought to drive their competitors out of business. The unions, like McCready, should be deemed to have standing because their injuries were "a necessary step in effecting the ends of the illegal conspiracy."238

The carpenters' unions' injury in Associated General Contractors $^{239}$ also is "inextricably intertwined"240 with the antitrust violation alleged, but in a different sense. Injury to the carpenters' unions was not a means to the boycott of union-signatory subcontractors; it was a necessary concomitant, since only subcontractors who were signatory to collective bargaining agreements with the unions were subject to the group boycott. This was the basis for the Ninth Circuit's conclusion that the injury to the carpenters' unions was not merely foreseeable, but also intended. ${ }^{241}$

The Court's opinion in McCready suggests that such an intended injury would not be too remote. Although the Court rejected specific intent as a criteria for remoteness, ${ }^{242}$ it apparently did so in order to expand the class of section 4 plaintiffs beyond those whose injuries were specifically intended; when plaintiffs are intended victims of antitrust violations, a fortiori their injuries would not be too remote.

\footnotetext{
234 See supra text accompanying notes 198-200.

sss 102 S. Ct. at 2549.

238 See supra note 54 and accompanying text.

${ }^{287}$ Seafarers Int'l Union v. American Commercial Lines, No. 80-1565 (E.D. La. Nov, 12, 1980). See supra notes 61-63 and accompanying text.

$283102 \mathrm{~S}$. Ct. at 2549.

${ }^{238}$ California State Council of Carpenters v. Associated Gen. Contractors, 648 F.2d 527 (9th
}

Cir. 1980), cert. granted, 102 S. Ct. 998 (1982). See supra text accompanying notes 13-14.

$240 \mathrm{McC}$ ready, $102 \mathrm{~S}$. Ct. at 2551.

24 Associated Gen. Contractors, 648 F.2d at 538.

242 102 S. Ct. at 2548. 
Nor would the injury to the carpenters' unions be too remote in terms of the antitrust injury concept. Their injury "flows from that which makes defendants' acts unlawful," since the anticompetitive purpose and effect of the group boycott - that which makes the Associated General Contractors' conduct a section 1 violation - causes union-signatory subcontractors to lose jobs on construction projects and that, in turn, causes the carpenters' unions to lose dues income and other fees.

In sum, organized labor's standing to sue for treble damages will depend upon the relationship between the particular antitrust violation and the particular injury to business or property alleged. The standing approach adopted in McCready is a flexible standard, still in its infancy, and whether a union or unionized employees will have section 4 standing cannot be predicted in all cases. But unions or unionized employees clearly will have standing to sue for treble damages based on an employer's unlawful conduct in many of the cases discussed in Part $\mathrm{I}^{243}$

\section{Conclusion}

The analysis and arguments of this Article can now be stated with respect to the major issues before the Supreme Court in Associated General Contractors. ${ }^{244}$

First, the Court should affirm the Ninth Circuit's view that the unions' complaint states a sufficient cause of action under section 1 of the Sherman Act. The appellate court reached that conclusion by comparing the challenged employers' boycott before it to the boycott of nonsignatory subcontractors resulting from the hot cargo agreement challenged in Connell. ${ }^{248}$ It considered the employers' group boycott to be "the obverse of the situation described in Connell."246 Rather than relying so heavily on Connell, the Supreme Court should analyze the employers' conduct in terms of section 1's traditional framework. As indicated above, ${ }^{247}$ such an analysis would lead to the same ultimate conclusion as the Ninth Circuit reached.

Second, the Court should affirm the Ninth Circuit's conclusion that the conspiring employers are not entitled to defend their conduct on the basis of the statutory labor exemption. The Court should sup-

21s See supra text accompanying notes 51-85.

344 California State Council of Carpenters v. Associated Gen. Contractors, 648 F.2d 527 (9th Cir. 1980), cert. granted, 102 S. Ct. 998 (1982).

${ }^{245} 648$ F.2d at 531-32 (citing Connell Construction Co. v. Plumbers \& Steamfitters Local Union No. 100, 421 U.S. 616 (1975)).

240 Id. at 532.

247 See supra text accompanying notes 51-53. 
plement the appellate court's analysis, based on the overall purpose of the Norris-LaGuardia Act ${ }^{248}$ and the statements and implications of certain Supreme Court decisions, ${ }^{248}$ with the legislative history discussed above, which clearly shows that the Norris-LaGuardia Act was not intended to protect employers from antitrust liability.

Third, the Court should use Associated General Contractors as an occasion to adopt a foreseeability test for resolving the remoteness issue in most antitrust standing cases. Not only would such a test be a logical outgrowth of the Court's analysis in $\mathrm{McCready}{ }^{250}$ it also would provide an objective standard with sufficient flexibility to accommodate the particular facts of each case.

\section{POSTSCRIPT}

After this Article went to press, the Supreme Court decided Associated General Contractors v. California State Council of Carpenters. ${ }^{251}$ The Court agreed with the Ninth Circuit that the unions' complaint stated a legally sufficient antitrust claim, ${ }^{252}$ but held that the unions lacked standing under section 4 of the Clayton Act to maintain a treble damage action. ${ }^{253}$ Justice Stevens, who wrote the majority opinion, did not address the employers' defense that their conduct was protected by the statutory and nonstatutory labor exemptions. In his lone dissent, Justice Marshall disagreed with the limitations the majority opinion imposed on the scope of section 4 standing. ${ }^{254}$

Because Justice Stevens deliberately eschewed "a black-letter rule that will dictate the result in every case,"255 the Court's decision does not require a denial of section 4 standing to unions in all cases. Moreover, the Court did not consider whether the unions had standing to sue for injunctive relief under section 16 of the Clayton Act. Nor did the majority opinion offer any guidance as to whether or in what circumstances employees would have standing to sue under sections 4 or 16 . Thus, although the Court's decision clearly limits organized labor's use of the antitrust laws, it still leaves room for some treble damage actions and does not in any way circumscribe organized labor's right to sue for injunctive relief.

\footnotetext{
24829 U.S.C. $\$ \S 101-115$ (1976).

249 See Associated Gen. Contractors, 648 F.2d at 532-36.

280 Blue Shield v. McCready, 102 S. Ct. 2540 (1982).

25151 U.S.L.W. 4139 (U.S. Feb. 22, 1983).

282 Id. at 4142.

268 Id. at $4146-47$.

234 Id. at 4147-48 (Marshall, J., dissenting).

${ }^{258}$ Id. at 4144.
} 